\title{
Nanotechnology for Plant Disease Management
}

\author{
Elizabeth A. Worrall ${ }^{1,+}{ }^{\oplus}$, Aflaq Hamid ${ }^{2,3, \dagger}$, Karishma T. Mody $^{1}$, Neena Mitter ${ }^{1, *}$ and \\ Hanu R. Pappu 2,* \\ 1 Centre of Horticultural Science, Queensland Alliance for Agriculture and Food Innovation, \\ The University of Queensland, Brisbane, QLD 4072, Australia; \\ elizabeth.worrall@uqconnect.edu.au (E.A.W.); k.mody@uq.edu.au (K.T.M.) \\ 2 Department of Plant Pathology, Washington State University, Pullman, WA 99164, USA; falak19@gmail.com \\ 3 Department of Plant Pathology, Sher-e-Kashmir University of Agricultural Sciences \& Technology of \\ Kashmir, Srinagar 190019, India \\ * Correspondence: n.mitter@uq.edu.au (N.M.); hrp@wsu.edu (H.R.P.) \\ $\dagger$ These authors contributed equally to this work.
}

Received: 15 November 2018; Accepted: 25 November 2018; Published: 28 November 2018

check for updates

\begin{abstract}
Each year, $20 \%-40 \%$ of crops are lost due to plant pests and pathogens. Existing plant disease management relies predominantly on toxic pesticides that are potentially harmful to humans and the environment. Nanotechnology can offer advantages to pesticides, like reducing toxicity, improving the shelf-life, and increasing the solubility of poorly water-soluble pesticides, all of which could have positive environmental impacts. This review explores the two directions in which nanoparticles can be utilized for plant disease management: either as nanoparticles alone, acting as protectants; or as nanocarriers for insecticides, fungicides, herbicides, and RNA-interference molecules. Despite the several potential advantages associated with the use of nanoparticles, not many nanoparticle-based products have been commercialized for agricultural application. The scarcity of commercial applications could be explained by several factors, such as an insufficient number of field trials and underutilization of pest-crop host systems. In other industries, nanotechnology has progressed rapidly, and the only way to keep up with this advancement for agricultural applications is by understanding the fundamental questions of the research and addressing the scientific gaps to provide a rational and facilitate the development of commercial nanoproducts.
\end{abstract}

Keywords: nanotechnology; agriculture; nanopesticides; targeted delivery; disease management

\section{Introduction}

Plant pests and pathogens cause significant reductions in crop production, with estimated global losses of $20 \%-40 \%$ per year [1]. Current pest management relies heavily on the application of pesticides, such as insecticides, fungicides, and herbicides. In spite of many advantages, like high availability, fast action, and reliability, pesticides have harmful side effects towards non-target organisms, the resurgence of the pest population, and the development of resistance [2]. Furthermore, it is estimated that $90 \%$ of applied pesticides are lost during or after application $[2,3]$. As a result, there is an increased motivation to develop cost-efficient, high-performing pesticides, that are less harmful to the environment.

Nanotechnology has led to the development of new concepts and agricultural products with immense potential to manage the aforementioned problems. Nanotechnology has substantially advanced in medicine and pharmacology, but has received comparatively less interest for agricultural applications [4,5]. The use of nanotechnology in agriculture is currently being explored in plant hormone delivery, seed germination, water management, transfer of target genes, nanobarcoding, nanosensors, and controlled release of agrichemicals [6]. Material scientists have engineered nanoparticles 
with desired characteristics, like shape, pore size, and surface properties, so that they can then be used as protectants or for precise and targeted delivery via adsorption, encapsulation, and/or conjugation of an active, such as a pesticide [7]. As agricultural nanotechnology develops, the potential to provide a new generation of pesticides and other actives for plant disease management will greatly increase.

The use of nanoparticles to protect plants can occur via two different mechanisms: (a) nanoparticles themselves providing crop protection, or (b) nanoparticles as carriers for existing pesticides or other actives, such as double-stranded RNA (dsRNA), and can be applied by spray application or drenching/soaking onto seeds, foliar tissue, or roots. Nanoparticles, as carriers, can provide several benefits, like (i) enhanced shelf-life, (ii) improved solubility of poorly water-soluble pesticides, (iii) reduced toxicity, and (iv) boosting site-specific uptake into the target pest [6]. Another possible nanocarrier benefit includes an increase in the efficacy of the activity and stability of the nanopesticides under environmental pressures (UV and rain), significantly reducing the number of applications, thereby decreasing toxicity and reducing their costs (Figure 1).

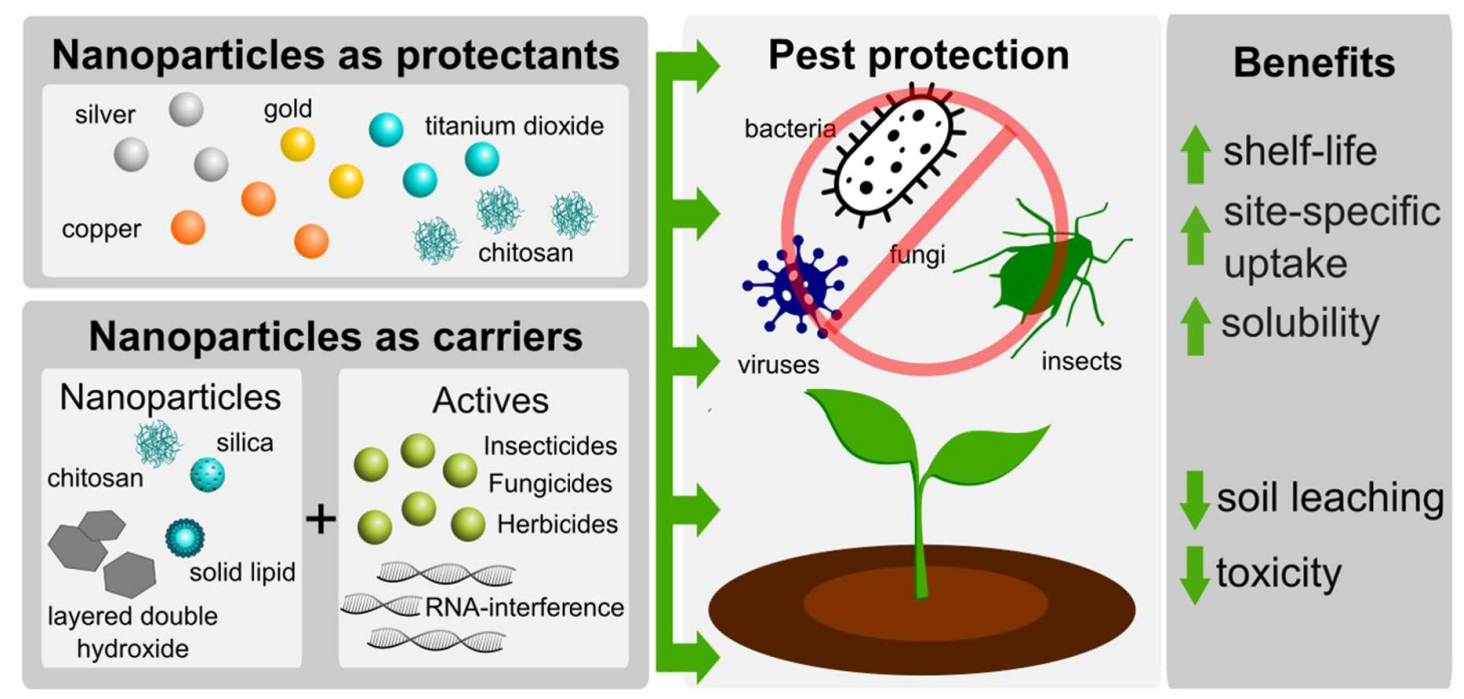

Figure 1. Nanomaterials as protectants or carriers to provide crop protection. This schematic shows different nanomaterials as either protectants or carriers for actives such as insecticides, fungicides, herbicides, or RNA-interference molecules, targeting a wide range of pests and pathogens. It also highlights the potential benefits of nanomaterial applications, such as improved shelf-life, target site-specific uptake, and increased solubility, while decreasing soil leaching and toxicity.

In this review, we discuss the recent advances in plant disease management using nanoparticles themselves as protectants, as well as nanoparticles as carriers for insecticides, fungicides, herbicides, and dsRNA for RNA-interference (RNAi)-mediated protection. For years, nanotechnology has shown the potential to create a strong footprint for developing effective formulations. However, the authors believe that agricultural nanotechnology research is not reaching its potential. due to the scarcity of commercial applications. Of the 84 papers that investigated nanoparticle-loaded insecticides, fungicides, or herbicides (published since October 2018), only two papers have conducted field trials. In addition, only 24 papers studied the environmental issues such as non-target toxicity or soil leaching, and only 46 papers investigated the developed formulations against a target pest (Figure 2). It is critical that research continues its shift towards testing on crop plants, target pests, and conducting short-term as well as long-term field trials for the advancement of agricultural nanotechnology. 


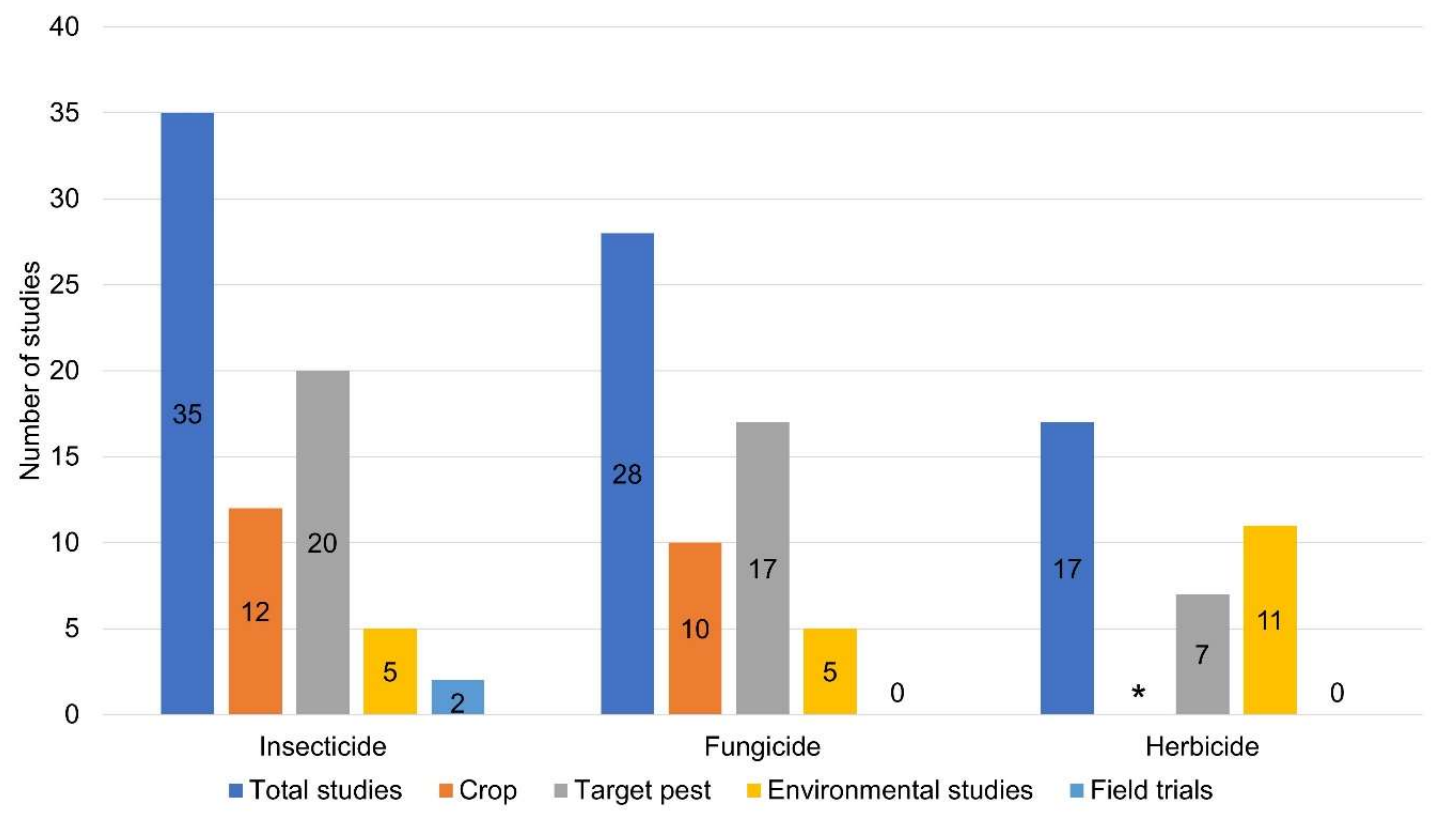

Figure 2. Studies conducted on insecticides, fungicides, and herbicides (including biocides) loaded onto nanoparticles. Insecticides: 35 studies have been conducted to date, where 12 tested their nano-insecticide on crop plants, 20 against the target pest, 5 on environmental issues, such as non-target toxicity or soil leaching, and 2 trials were done in field conditions. Fungicides: 28 studies have been conducted to date, where 10 tested their nano-insecticide on crop plants, 17 against the target pest, 5 on environmental issues, such as non-target toxicity or soil leaching, and no trials have been conducted in field conditions. Herbicides: 17 studies have been conducted to date, where 7 were tested against the target pest, 11 on environmental issues, such as non-target toxicity or soil leaching, and no trials have been conducted in field conditions. ${ }^{*}$ Crop host experiments were not included, since some herbicides are non-selective.

\section{Types of Nanoparticles for Plant Disease Management}

\section{Nanoparticles as Protectants}

Nanoparticles are materials that range between 10 to 100 nanometers (nm), and can be designed with unique chemical, physical, and biological properties, to distinctively differ from those of their molecular and bulk counterparts [8]. Nanoparticles alone have the potential to be directly applied to plant seeds, foliage, or roots for protection against pest and pathogens, such as insects, bacteria, fungi, and viruses. Metal nanoparticles such as silver, copper, zinc oxide, and titanium dioxide have been intensively researched for their antibacterial and antifungal properties, and are known for their antiviral properties [9-11]. This section gives a brief overview and an update on current literature reviews pertaining to the individual nanoparticles that already exist [9,12-14].

Recently, silver nanoparticles have increased in popularity, due to "green synthesis" production in plants, bacteria, fungi, or yeast [15]. Silver nanoparticles have shown antifungal inhibition of Alternaria alternata, Sclerotinia sclerotiorum, Macrophomina phaseolina, Rhizoctonia solani, Botrytis cinerea, and Curoularia lunata by well diffusion assay [16]. When silver nanoparticles were sprayed onto bean leaves, complete suppression of sun-hemp rosette virus was observed [17]. Elbeshehy et al. [18] further showed that faba bean plants challenged with bean yellow mosaic virus, and sprayed with silver nanoparticles, produced remarkably better results when the nanoparticles were applied $24 \mathrm{~h}$ post-infection, compared to spray application before infection, or simultaneously at the time of inoculation. Silver nanoparticles have shown immense potential for plant disease management against fungal and bacterial pathogens, but there are significant hurdles associated to them, such as production, toxicity, and soil interaction $[9,12]$. 
Other commonly used metal nanoparticles include copper, titanium dioxide, and gold. Nanoparticles, such as copper and titanium dioxide, are more commonly being utilized for fertilizer with little research into plant disease management. The research covering titanium dioxide, silver, and copper nanoparticles for antimicrobial properties, and aluminum nanoparticles as an insecticidal dust, has been highlighted [9]. Furthermore, titanium dioxide nanoparticles in fertilizers have produced protection from bacteria and inactivation of viruses (as summarized in Sadeghi et al. [13]). Introducing poly-dispersed gold nanoparticles via a mechanical abrasive was seen to melt and dissolve the Barley yellow mosaic virus particles conferring resistance to the plant [19].

Chitosan is another popular nanoparticle that has favorable biological properties, such as biodegradability, biocompatibility, non-allergenicity, and antimicrobial activity, with low toxicity to animals and humans [20]. Chitosan nanoparticles induce viral resistance in plant tissues by protecting them against infections caused by the mosaic virus of alfalfa, snuff, peanut, potato, and cucumber [21-23]. Chitosan nanoparticles have shown antimicrobial properties, such as controlling Fusarium crown, root rot in tomato, Botrytis bunch rot in grapes, and Phyricularia grisea in rice [24], but are less effective against bacteria [14]. Malerba and Cerana [14] summarized potential mechanisms that lead to the antimicrobial effects of chitosan, such as agglutination, disruption of the cell membrane, inhibition of $\mathrm{H}^{+}$-ATPase activity, inhibition of toxin production and microbial growth, inhibition of the synthesis of messenger RNA and proteins, and blockage of nutrient flow. Antiviral effects have been observed in beans against Bean mild mosaic virus and, in tobacco, against Tobacco mosaic virus and Tobacco necrosis virus [14]. Chitosan has also shown effectiveness against oleander aphid (Aphis nerii), cotton leafworm (Spodoptera littoralis), root-knot nematode (Meloidogyne javanica), and nymphs of the spear psylla (Cacopsylla pyricola) [14]. Chitosan holds promise as both nanoparticles alone and has shown to have an enormous potential as a nanocarrier.

\section{Nanoparticles that Act as Carriers}

Nanoparticles are also commonly used as carriers to entrap, encapsulate, absorb, or attach active molecules to develop effective agricultural formulations. The common nanoparticles which have been used as carriers for insecticides, fungicides, herbicides, and RNAi-inducing molecules, are summarized below.

Silica nanoparticles can be easily synthesized with a controlled size, shape, and structure, making them highly advantageous delivery vehicles [25]. They are commonly produced in a spherical shape with pore-like holes; for example, porous hollow silica nanoparticles (PHSNs) or mesoporous silica nanoparticles (MSNs). PHSN and MSN commonly load the pesticide into the inner core to protect the active molecules and, therefore, provide a sustained release. The shell structure of PHSNs protect the active molecules inside the nanoparticles against degradation by UV light. The literature suggests that silicon has already been used to enhance plant tolerance against various abiotic and biotic stresses and, therefore, silica nanoparticles seem to be the natural choice for the development of agri-products for pests [26].

Chitosan nanoparticles have low solubility in aqueous media, due to their hydrophobic properties [24,27]. As a result, chitosan is commonly mixed with a copolymer, organic and inorganic, to improve its solubility [24]. Chitosan has reactive amine and hydroxyl groups, allowing modification, graft reactions, and ionic interactions, enabling improvement of chitosan properties [27]. Chitosan adheres well to the epidermis of leaves and stems, prolonging the contact time and facilitating the uptake of the bioactive molecules [14].

Solid lipid nanoparticles (SLNs) are similar to emulsions, and are composed of lipids that are solid at room temperature. An advantage of SLNs is that they provide a matrix to entrap lipophilic active molecules without the use of organic solvents [28]. Furthermore, SLNs can also provide controlled release of various lipophilic components, due to decreased mobility of the active in the solid matrix $[28,29]$. Surfactants are used to stabilize the SLN when dispersed into water [5]. Their main 
drawbacks are that they have a low loading efficiency, and the active may leak out of the structure during storage [30].

Layered double hydroxides (LDHs) are clays that form into hexagonal sheets with layers of the active molecules trapped in the interlayer space [31]. LDH nanoparticles breakdown under acidic conditions, such as the addition of moisture and carbon dioxide from the atmosphere [32]. Positively charged delaminated LDH lactate nanoparticles have been shown to facilitate the transport of biologically active materials across the plant cell wall barrier [33].

Silica, chitosan, SLN, and LDH nanoparticles have been utilized as common carriers for plant disease management. The individual studies using these nanoparticles, and less frequently used nanoparticle types, are discussed in-depth in the sections categorized by insecticide, fungicide, herbicide, or RNAi.

\section{A Brief Guide to Insecticides, Fungicides, and Herbicides}

This section gives a brief outline on the types of pesticides and their classification system, designed to aid in their correct usage, and the prevention of pesticide resistance. Insecticides can be classified into systemic (absorbed by the plant) or contact insecticides (direct contact required), and can be classified into at least 55 different chemical classes, grouped according to physiological functions affected: nerve/muscle, growth, respiration, midgut, or unknown/non-specific [34]. Importantly, there are 30 modes of action (MoA) (including multiple sites and unknown groups) which are required to be applied, in rotation, to prevent insecticide resistance [34]. Fungicides work by contact (barrier on the plant that is not absorbed) or by penetration (absorbed by the plant at various levels of systemic movement). Spray coverage of fungicides is extremely important, since systemic movement within the whole plant is uncommon. Fungicides are split into 49 Fungicide Resistance Action Committee (FRAC) codes with 14 different MoA groups [35]. Herbicides can be selective by killing only target weeds, or non-selective by killing all vegetation. Spray application of herbicides can be applied at pre-plant (non-selective applied to the soil before planting), pre-emergence (before weed seedlings emerge through the soil) or post-emergence (weed seedlings already emerged from the soil). There are 23 Herbicide Resistant Action Committee (HRAC) groups of herbicides. Rotation within these groups is critical to prevent pesticide resistance.

\section{Nanoparticles as Carriers for Insecticides}

Loading insecticides into nanoparticles first started in the early 2000s. Since then, conventional insecticides (27 studies) and bioactive compounds with insecticidal properties (13 studies) have been conducted with a range of nanoparticles (Table 1). These studies have explored eight different MoA and a range of essential oils (not included in Insecticide Resistance Action Committee (IRAC) classification). The most commonly investigated nanoparticle carriers were silica (8 studies), chitosan (11 studies), and lipids (4 studies). Spodoptera litura (5 studies), Tetranychus urticae (4 studies), and Helicoverpa armigera (4 studies) were the most popular target pests. In these studies, the researchers aimed to improve low water-solubility, decrease volatilization, improve stability, and provide slow release of the active molecules. 
Table 1. Summary of studies utilizing nanoparticles as carriers of insecticides or actives that target insect pests.

\begin{tabular}{|c|c|c|c|c|c|}
\hline $\begin{array}{l}\text { Insecticide (IRAC MoA } \\
\text { Classification }{ }^{\text {a) }}\end{array}$ & Nanoparticle & Crop & Target Pest & Toxicity or Soil Leaching & Reference \\
\hline Chlorpyrifos (1B) & PVC & Birch and southern yellow pine & - & - & [36] \\
\hline A. arborescens L. essential oil * & SLN & - & - & - & [37] \\
\hline Avermectin (6) & PHSN & - & - & - & [38] \\
\hline Avermectin (6) & PHSN & - & - & - & [39] \\
\hline Avermectin (6) & PHSN & - & - & - & [40] \\
\hline Garlic essential oil * & PEG & Rice (harvested) & Red flour beetle (T. castaneum) & - & [41] \\
\hline Deltamethrin (3A) & Chitosan-coated beeswax SLN & - & - & - & [42] \\
\hline Deltamethrin (3A) & $\begin{array}{l}\text { Corn oil (liquid lipid) and } \\
\text { beeswax SLN }\end{array}$ & - & - & - & {$[43]$} \\
\hline Chlorfenapyr (13) & Silica & Brassica chinese & $\begin{array}{c}\text { Cotton bollworm (H. armigera) } \\
\text { P. xylostella }\end{array}$ & - & [44] \\
\hline Azadirachtin (UN) & Chitosan & - & - & - & [45] \\
\hline Chlorpyrifos (1B) & Chitosan/PLA & - & - & - & [46] \\
\hline Azadirachtin (UN) & Chitosan & - & $\begin{array}{l}\text { Tobacco cutworm (S. litura) culture } \\
\text { ovarian cell lines Sl-1 }\end{array}$ & - & [47] \\
\hline Imidacloprid (4A) & Sodium alginate & Plants (unspecified) & Leafhopper (Jassids) & Vero cells (monkey) & [48] \\
\hline $\begin{array}{l}\alpha \text {-pinene * } \\
\text { and } \\
\text { Linalool * }\end{array}$ & Silica & Castor leaf discs & $\begin{array}{l}\text { Tobacco cutworm (S. litura) } \\
\text { Castor semi-looper (A. janata) }\end{array}$ & - & [49] \\
\hline Abamectin (6) & Porous silica & - & - & - & [50] \\
\hline $\begin{array}{l}\text { Anacardic acid * } \\
\text { Abamectin (6) } \\
\text { Cyhalothrin (3A) }\end{array}$ & LDH & $\begin{array}{l}\text { Mustard leaves } \\
\text { (B. juncea) }\end{array}$ & Tobacco cutworm (S. litura) & - & [51] \\
\hline Fipronil (2B) & Silica shell (oil core) & - & Termites (C. acinaciformis) & - & [52] \\
\hline Avermectin (6) & Polydopamine & Cotton leaves and corn leaves & - & - & [53] \\
\hline Avermectin (6) & Polydopamine & - & - & - & [54] \\
\hline Thiamethoxam (4A) & Dendrimers & - & $\begin{array}{c}\text { Cotton bollworm cells and larvae }(H . \\
\text { armigera) }\end{array}$ & - & [55] \\
\hline$\lambda$-cyhalothrin (3A) & Hollow polymeric shell & - & - & Embryonic zebrafish (D. rerio) & [56] \\
\hline $\begin{array}{c}\text { Organochlorine pesticides (EPA } 8080 \\
\text { pesticide mix) (2A) }\end{array}$ & Polymer coated silver & - & - & $\begin{array}{l}\text { Mouse peritoneal } \\
\text { macrophages }\end{array}$ & [57] \\
\hline S. maritima-based herbal coils * & Silver & Cotton leaf discs & Tobacco cutworm (S. litura) & - & [58] \\
\hline PONNEEM * & Chitosan & - & Cotton bollworm larvae (H. armigera) & - & [59] \\
\hline Avermectin (6) & Polydopamine & $\begin{array}{l}\text { Cucumber } \\
\text { Broccoli }\end{array}$ & Aphids (unspecified) & - & [60] \\
\hline Avermectin (6) & Castor oil-based polyurethane & Corn leaves & - & - & [61] \\
\hline Azadirachtin (UN) & Zinc oxide and chitosan & - & Groundnut bruchid (C. serratus) & - & [62] \\
\hline $\begin{array}{l}\text { Carvacrol * } \\
\text { Linalool * }\end{array}$ & Chitosan & - & Mite (T. urticae) & - & [63] \\
\hline
\end{tabular}


Table 1. Cont

\begin{tabular}{|c|c|c|c|c|c|}
\hline $\begin{array}{l}\text { Insecticide (IRAC MoA } \\
\text { Classification a) }\end{array}$ & Nanoparticle & Crop & Target Pest & Toxicity or Soil Leaching & Reference \\
\hline Geraniol * & Chitosan/Gum Arabic & - & Whitefly (B. tabaei) & - & [64] \\
\hline S. hortensis L. essential oil * & Chitosan/TPP & - & Mite (T. urticae) & - & [65] \\
\hline $\begin{array}{c}\text { Geraniol and } \\
R \text {-citronellal essential oils * }\end{array}$ & Zein & - & Mite (T. urticae) & $\begin{array}{l}\text { Bean seed (P. vulgaris) } \\
\text { Two fibroblast cell lines } \\
\text { (hamster and mouse) }\end{array}$ & [66] \\
\hline Nicotine (4B) & Chitosan/TPP & - & House fly (M. domestica) & - & [67] \\
\hline $\begin{array}{l}\text { Imidacloprid (4A) } \\
\text { Cyfluthrin (3A) }\end{array}$ & Magnetic nanocomposites & - & - & - & [68] \\
\hline $\begin{array}{l}\text { Carvacrol * } \\
\text { Linalool * }\end{array}$ & Chitosan & Bean leaf discs & $\begin{array}{c}\text { Corn earworm (H. armigera) and } \\
\text { Mites (T. urticae) }\end{array}$ & $\begin{array}{l}\text { Mouse fibroblast and } \\
\text { pulmonary cells } \\
\text { Maize (Z. mays) }\end{array}$ & [69] \\
\hline Avermectin (6) & PHSN & Brassica oleracea & P. xylostella larvae & - & [70] \\
\hline
\end{tabular}

In this table, the tested insecticide with the IRAC MoA group [34] and nanocarrier are listed. Experiments conducted on crop plants, against targeted pests, or exploring environmental factors, such as off-target toxicity and soil leaching, are specified. Of the 30 possible IRAC MoA groups (including multiple site and unknown groups), seven groups are represented; -, not tested; A. arborescens, Artemisia arborescens; A. craccivora, Aphis craccivora; B. juncea, Brassica juncea; B. tabaei, Bemisia tabaei; C. acinaciformis, Coptotermes acinaciformis; C. serratus, Caryedon serratus O.; D. rerio, Danio rerio; H. armigera, Helicoverpa armigera; IRAC, Insect Resistance Action Committee; LDH, layered double hydroxide; $M$. domestica, Musca domestica; MoA, mode of action; N. rileyi, Nomuraea rileyi; PEG, polyethylene glycol; PHSN, porous hollow silica nanoparticles; PLA, polylactide; P. ricini, Pericallia ricini; PVC, polyvinylchloride; P. vulgaris, Phaseolus vulgaris; P. xylostella, Plutella xylostella; S. hortensis, Satureja hortensis L.; S. litura, Spodoptera litura; SLN, solid lipid nanoparticle; S. maritima, Suaeda maritima; T. castaneum,

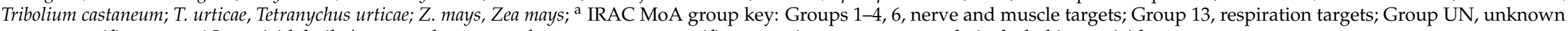
or non-specific targets; * Insecticidal oils/extracts that are not known to act at specific target sites are not currently included in pesticide groups. 
Insecticides that have low water-solubility require organic solvents to help solubilize the pesticide, which increases the cost and toxicity of the insecticide. Instead, nanoparticles can be used to increase the solubility, thus reducing the toxicity. To date, low-water-soluble insecticides have been successfully loaded into modified chitosan [45-47,63] and porous silica [50]. However, none of these studies tested for reduced environmental toxicity. Using modified chitosan nanoparticles to load the hydrophobic insecticide azadirachtin, Lu et al. [47] showed favorable inhibition of cell proliferation in S. litura ovarian cell lines, and sustained drug release. In another study, Liu et al. [55] showed an increase in uptake and higher mortality when $H$. armigera larvae were subjected to dendrimers loaded with hydrophobic thiamethoxam. Interestingly, H. armigera is not normally susceptible to thiamethoxam. However, when loaded onto dendrimer nanoparticles, a significant increase in toxicity was observed. An increase in mortality was also seen when anacardic acid (a cashew nutshell liquid extract) was intercalated into LDH nanoparticles [51]. When directly sprayed onto the skin of $S$. litura or applied onto mustard leaves, an increase in mortality was observed with the LDH formulation, compared to anacardic acid alone. These studies highlight the potential benefit of using nanoparticles to improve the solubility of active.

Evaporation or volatilization of the active is another common issue associated with the loss of insecticide post application. Essential oils are known for inducing insecticidal effects, but rapidly evaporate due to their chemical instability in the presence of air, light, moisture, and high temperatures [37]. Lai et al. [37] sprayed SLN nanoparticle-encapsulated Artemisia arborescens L. essential oil into glass vials, and observed $45.5 \%$ evaporation with an initial burst release, compared to $80 \%$ evaporation of essential oil alone, after $48 \mathrm{~h}$. In another study, garlic essential oil was encapsulated into polyethylene glycol (PEG) and applied to harvested rice, then infested with red flour beetles (Tribolium castaneum) [41]. After 5 months, $80 \%$ mortality was observed with the nanoparticle formulation, compared to $11 \%$ mortality with essential oil alone. Similarly, Rani et al. [49] treated castor leaves with $\alpha$-pineneand linalool-encapsulated silica dispersed in acetone. The authors reported that $S$. litura and castor semilooper fed on treated leaves had lower feeding activity, leading to death due to starvation. These studies successfully showed that the association of the active with nanoparticles improved the volatility issues.

Another motive to develop nano-insecticides is to increase the stability of the active molecules and provide a sustained release that would allow for a decrease in insecticide usage and improved safety. In field trials, Kumar et al. [71] found that okra bhindi plants sprayed with sodium alginate-encapsulated imidacloprid were just as effective as imidacloprid alone. Song et al. [44] in another field study, treated Brassica chinese with silica-encapsulated chlorfenapyr to achieve similar or more effective control against the diamondback moth (Plutella xylostella) over a three-day period. Another study found that feeding termites with fipronil, loaded into nanoparticles with a silica shell of larger shell thickness and an oil core, provided a sustained release with no initial burst release, thus allowing the worker termites to potentially carry the bait back to the nest [52]. Compared to the commercial insecticide, silica-loaded fipronil extended the $100 \%$ mortality window by 3 days, allowing better elimination of the colony. Jenne et al. [62] loaded azadirachtin onto zinc oxide or chitosan nanoparticles, and tested the efficacy over 180 days in groundnut bruchid storage conditions. Neem seed kernel extract, loaded into zinc oxide nanoparticles, contained groundnut bruchid with $54.61 \%$ weight loss compared to the other formulations tested.

Slow release of active molecules could also potentially decrease the toxicity of the insecticides. To date, four studies have tested if sustained release of insecticides from nanoparticles could decrease toxicity. For example, when testing for cytotoxicity of imidacloprid loaded onto sodium alginate nanoparticles, Kumar et al. [71] claimed "that these experiments clearly reveal that at this concentration loaded-pesticide nanoformulation is very less toxic than original pesticide". However, only a small difference was observed, and no statistical analysis was conducted. On the other hand, Meredith et al. [56] observed a decrease in toxicity effects on zebrafish with hollow polymeric shell nanoparticle-encapsulated $\lambda$-cyhalothrin, and the larger micron-sized particles of the same composition, 
when compared to the unformulated insecticide $\lambda$-cyhalothrin. Oliveira et al. [66] also observed a decrease in toxicity in mouse fibroblast cell lines when treated with zein nanoparticle-encapsulated botanical repellents, compared to the botanical repellents alone. Similarly, carvacrol and linalool, loaded into chitosan nanoparticles, also decreased the toxicity in two fibroblast cell lines [69]. More studies are required to confirm the reductions in insecticide toxicity due to nanoparticle encapsulation, but these studies provide a promising start.

\section{Nanoparticles as Carriers for Fungicides}

Starting in 1997, initial studies on nanofungicides were conducted on incorporating fungicides into solid wood [36,72-74]. Since then, conventional fungicides (20 studies) and biocides with antifungal properties (6 studies) have been conducted with a wide range of nanoparticles (Table 2). Nine FRAC groups, and a range of essential oils not included in the fungicide groups, were studied. The most commonly investigated nanoparticle carriers were polymer mixes, silica, and chitosan. A wide range of fungi were used to check the efficiency of the nanofungicide. However, few plants were tested, nor were there many toxicity studies. Similar to insecticides, nanoparticles were exploited to improve low-water-solubility issues, decrease volatilization, and improve stability while providing a slow sustained release. 
Table 2. Summary of studies utilizing nanoparticles as carriers of fungicides or actives that target fungi.

\begin{tabular}{|c|c|c|c|c|c|}
\hline Fungicide (FRAC Code ${ }^{\text {a) }}$ ) & Nanoparticle & Crop & Target Pest & Toxicity or Soil Leaching & Reference \\
\hline $\begin{array}{c}\text { Tebuconazole (3) } \\
\text { Chlorothalonil (M 05) }\end{array}$ & PVP and PVP copolymer & Southern pine sapwood & G. trabeum & - & [36] \\
\hline $\begin{array}{l}\text { Tebuconazole (3) } \\
\text { Chlorothalonil (M 05) }\end{array}$ & PVP and PVP copolymer & Southern yellow pine & G. trabeum & - & [73] \\
\hline $\begin{array}{l}\text { Tebuconazole (3) } \\
\text { Chlorothalonil (M 05) } \\
\text { KATHON } 930 \text { (32) }\end{array}$ & PVC & Birch and Southern yellow pine & $\begin{array}{l}\text { Turkey tail (T. versicolor) } \\
\text { G. trabeum }\end{array}$ & - & [74] \\
\hline $\begin{array}{c}\text { Tebuconazole (3) } \\
\text { Chlorothalonil (M 05) }\end{array}$ & PVP and PVP copolymer & Birch and Southern yellow pine & $\begin{array}{l}\text { Turkey tail (T. versicolor) } \\
\text { G. trabeum }\end{array}$ & - & [72] \\
\hline Tebuconazole (3) & Bacterial ghosts & Barley, wheat, and cucumber & $\begin{array}{l}\text { E. graminis, L. nodorum, } \\
\text { P. teres and S. fuliginea }\end{array}$ & $\begin{array}{l}\text { Barley (necrosis and } \\
\text { yellowing) }\end{array}$ & [75] \\
\hline Validamycin (26) & PHSN & - & - & -0 & [76] \\
\hline Validamycin (26) & Calcium carbonate & - & R. solani & - & [77] \\
\hline Tebuconazole (3) & PHSN & - & - & - & [78] \\
\hline $\begin{array}{l}\text { Bioactive compounds from } \\
\text { Chaetomium spp. * }\end{array}$ & PLA & - & - & - & [79] \\
\hline Metalaxyl (4) & MSN & - & - & Soil sorption & [80] \\
\hline Pyraclostrobin (11) & Chitosan-PLA graft copolymer & - & C. gossypii Southw. & - & [81] \\
\hline Flusilazole (3) & Chitosan-PLA graft copolymer & - & - & - & [82] \\
\hline $\begin{array}{l}\text { Bioactive compounds from } \\
\text { Chaetomium spp. * }\end{array}$ & PLA & - & - & - & [79] \\
\hline $\begin{array}{l}\text { Carbendazim (1) } \\
\text { Tebuconazole (3) }\end{array}$ & Polymeric and SLN & Bean seeds & - & $\begin{array}{l}\text { Mouse fibroblast cells and soil } \\
\text { sorption }\end{array}$ & [83] \\
\hline 7 different volatile essential oils * & MSN & - & A. niger & - & [84] \\
\hline Kaempferol * & Lecithin/Chitosan & - & $\begin{array}{l}\text { F. oxysporum } \\
\text { A. ochraceus, A. niger, A. flavus, A. solani, }\end{array}$ & - & [85] \\
\hline Zataria multiflora essential oil * & SLN & - & $\begin{array}{l}\text { R. solani and } \\
\text { Black bread mold (R. stolonifera) }\end{array}$ & - & [86] \\
\hline Ferbam (M 03) & Gold & Tea leaves & - & - & [87] \\
\hline Pyraclostrobin (11) & Chitosan/MSN & - & P. asparagi & - & [88] \\
\hline Carbendazim (1) & Chitosan/Pectin & $\begin{array}{l}\text { Cucumber } \\
\text { Maize } \\
\text { Tomato }\end{array}$ & $\begin{array}{l}\text { F. oxysporum and } \\
\text { A. parasiticus }\end{array}$ & E. coli and S. aureus & [89] \\
\hline Pyrimethanil (9) & MSN & Cucumber & - & - & [90] \\
\hline $\begin{array}{l}\text { Carbendazim (1) } \\
\text { Metalaxyl (4) } \\
\text { Myclobutanil (3) }\end{array}$ & Magnetic nanocomposites & - & - & - & [68] \\
\hline Tebuconazole (3) & & & & & \\
\hline Prochloraz (3) & PHSN & Cucumber & B. cinerea & - & [91] \\
\hline Clove essential oil * & Chitosan & - & A. niger & - & [92] \\
\hline
\end{tabular}


Table 2. Cont.

\begin{tabular}{|c|c|c|c|c|c|}
\hline Fungicide (FRAC Code ${ }^{\text {a }}$ ) & Nanoparticle & Crop & Target Pest & Toxicity or Soil Leaching & Reference \\
\hline Tebuconazole (3) & & & & & \\
\hline Propineb (M 03) & Silver & - & B. maydis & - & [93] \\
\hline \multirow{4}{*}{$\begin{array}{c}\text { Fludioxonil (12) } \\
\text { Cymbopogon martini essential oil * } \\
\text { Azoxystrobin (11) } \\
\text { Difenoconazole (3) } \\
\text { Pyraclostrobin (11) }\end{array}$} & & & & & \\
\hline & Chitosan & Maize grains & F. graminearum & - & [94] \\
\hline & PBS/PLA & - & - & Zebrafish & [95] \\
\hline & MSN & - & P. asparagi & - & [96] \\
\hline
\end{tabular}

In this table, the tested fungicide with the FRAC MoA group [35] and nanocarrier are listed. Experiments conducted on crop plants, against targeted pests or exploring environmental factors such as off-target toxicity and soil leaching are specified. Of the 49 possible FRAC MoA codes, nine groups are represented; -, not tested; A. flavus, Aspergillus flavus; A. niger, Aspergillus niger; A. ochraceus, Aspergillus ochraceus; A. parasiticus, Aspergillus parasiticus; A. solani, Alternaria solani; B. maydis, Bipolaris maydis; B. cinerea, Botrytis cinerea; C. gossypii Southw., Colletotrichum gossypii Southw.; E. coli, Escherichia coli; E. graminis, Erysiphe graminis; F. graminearum, Fusarium graminearum; F. oxysporum, Fusarium oxysporum; FRAC, Fungicide Resistance Action Committee; G. trabeum, Gloeophyllum trabeum; L. nodorum, Leptosphaeria nodorum; MSN, mesoporous silica nanoparticles; P. asparagi, Phomopsis asparagi (Sacc.); PBS, poly (butylene succinate); P. asparagi, Phomopsis asparagi; PHSN, porous hollow silica nanoparticles; PLA, polylactide; PVC, polyvinylchloride; PVP, polyvinylpyridine; P. teres, Pyrenophora teres; R. solani, Rhizoctonia solani; R. stolonifera, Rhizopus stolonifera; S. aureus, Staphylococcus aureus; SLN, solid lipid nanoparticle; S. fuliginea, Sphaerotheca fuliginea; T. versicolor, Trametes versicolor; Z. mays, Zea mays; ${ }^{a}$ FRAC code key: Groups 4, 32, nucleic acids synthesis; Groups 1, 3, cytoskeleton and motor proteins; Group 11, respiration; Group 9, amino acids and protein synthesis; Group 3, sterol biosynthesis in membranes; Group 26 cell wall biosynthesis; Groups M 03, M 05, chemicals with multi-site activity; ${ }^{*}$ Insecticidal oils, extracts, or other active that are not known to act at specific target sites are not currently included in pesticide groups. 
Hatfaludi et al. [75] used nanosized bacterial ghosts, non-denatured empty cell envelopes of Gram-negative bacteria, to increase adherence to the leaf surface and improve the low water-solubility of tebuconazole. Pectobacterium cypripedii was picked as the nanosized bacterial ghost, due to its ability to adhere to plants. Of the six plants tested (rice, soya, cabbage, cotton, barley, and corn), fluorescently labelled ghosts without a loaded fungicide adhered best to rice leaves ( $55 \%$ remaining), and soya leaves the lowest (10\% remaining), when treated with heavy simulated rain in glasshouse conditions. All six plants were compared with ghost-loaded tebuconazole or with two tebuconazole commercial treatments (WP 25 and EW 250) against a wide range of fungi (see Table 2). Plants that were not subjected to rainfall showed similar or higher protection to the commercial products with one exception. When the plants were subjected to heavy rain $1 \mathrm{~h}$ post-treatment, and challenged with fungus, the majority of groups did not perform as well as the commercial products with one exception. However, when washed $24 \mathrm{~h}$ post-treatment, ghost-loaded tebuconazole was equal to, or greater than, WP 25 treatments, but EW 250-treated controls were generally more efficient.

Pyraclostrobin, another low-water-soluble fungicide, was loaded onto chitosan-lactide copolymer nanoparticles at different concentrations [81]. Three and five days post-application, they found that the nanofungicide was either similar to, or less efficient at preventing inhibition of C. gossypii, when compared to commercial pyraclostrobin. However, an increase in inhibition was observed at 7 days post-treatment, compared to active alone [81]. In another trial, kaempferol (another low-soluble fungicide) loaded onto lecithin/chitosan showed $67 \%$ inhibition efficacy after 60 days storage on a Fusarium oxysporum-infected Petri dish [85].

In a series of studies, tebuconazole and chlorothalonil were loaded into a wide range of nanoparticles to improve the low solubility of the fungicides for deployment into solid woods [36,72-74]. All four studies tested the mass lost due to decay from Gloeophyllum trabeum in southern yellow pine wood over 50-55 days (later trials also included birch, Trametes versicolor, KATHON 930, and the insecticide chlorpyrifos). Hydrophobic chlorothalonil encapsulated into nanoparticles were not as efficient, due to the size and stability of the formulation, but with an increase in concentration, minimal decay of the wood due to fungal infection was achieved [74]. Nanoparticle-loaded tebuconazole was able to drastically decrease the amount of fungicide delivered (from ca. $2 \mathrm{~kg}$ active $/ \mathrm{m}^{3}$ to $0.2 \mathrm{~kg} / \mathrm{m}^{3}$ ) with negligible change in the amount of decay. Birch wood was harder to treat due to its smaller pit pores [74]. Chlorothalonil and tebuconazole, encapsulated with a surfactant-free method, created smaller median particle diameters and a more stable aqueous suspension, ultimately increasing uptake into the wood [72]. Negligible decay ( $5 \%$ or less mass loss) was achieved with drastically reduced concentrations compared to industry standards for both fungicides in southern pine exposed to G. trabeum and birch wood exposed to T. versicolor [72], clearly showing that the smaller, more stable surfactant-free nanoparticles afforded more resistance to fungal decay [72].

Essential oils with fungicidal properties evaporate too quickly for large scale commercial use. Janatova et al. [84] successfully encapsulated five individual essential oil components into MSN to show higher antifungal activity 14 days post-Aspergillus niger-infection, when compared to the bulk essential oil components. Similarly, SLNs have also been used to stabilize Zataria multiflora essential oil, providing protection against six fungi [86].

Leaching, the movement of water and chemicals through soil, is a major pesticide issue, but not many studies have been conducted with soil. Wanyika [80] loaded the fungicide metalaxyl onto MSNs, and observed leaching in soil between free metalaxyl (76\% release) and encapsulated metalaxyl $(11.5 \%)$ within a period of 30 days. When tested in water, the encapsulated metalaxyl had an increased release rate of $47 \%$ compared to the $11.5 \%$ seen in the soil, highlighting the importance of testing within the farming environment. Campos et al. [83] used two different types of nanoparticles, solid lipid or polymeric, and tested the cytotoxicity of carbendazim and/or tebuconazole loaded onto the nanoparticles. A decrease in toxicity with the nanoparticle-loaded pesticides was observed in preosteoblast and fibroblast mouse cell lines. In the soil leaching experiments, the addition of nanoparticles decreased the release rate in soil layer release experiments when compared to 
the commercial formulation. Wang et al. [95] treated zebrafish for $96 \mathrm{~h}$ with azoxystrobin and difenoconazole loaded into poly(butylene succinate) and poly(lactic acid) shells, and observed reduced toxicity compared to other formulations.

Slow release of the active molecules was achieved with nanosized calcium carbonate carrying validamycin [77]. Validamycin encapsulated in nanoparticles showed lower efficiency than validamycin alone, over a period of 1-7 days, in an in vitro assay against Rhizoctonia solani. However, two weeks later, the nanoparticle formulation showed slightly better results than the active alone, highlighting the efficacy of the nanoformulation over longer periods of time. Kumar et al. [89] found an increase in the fungal inhibition rate when carbendazim-loaded polymeric nanoparticles were tested against Fusarium oxysporum and Aspergillus parasiticus, compared to carbendazim alone. Phytotoxicity studies confirmed that the nanoformulated carbendazim was safer for germination and root growth of Cucumis sativa, Zea mays, and Lycopersicum esculentum seeds.

Zhao et al. [90] used MSNs to load pyrimethanil, and studied the uptake in cucumber plants over 48 days using high performance liquid chromatography tandem mass spectrometry. The uptake and the dosage of pesticide-loaded MSN in leaves had almost no effect on the distribution and dissipation rate in cucumber plants. Their study has shown that pyrimethanil-loaded MSN has a minimal risk of accumulating in the edible part of the plant. Zhao et al. [90]'s work furthers our knowledge and understanding of the distribution and translocation of MSN loaded with pesticides when applied as a foliar treatment.

\section{Nanoparticles as Carriers for Herbicides}

Most of the herbicide nanocarrier studies primarily focused on reducing the environmental impact caused by herbicides (Table 3). When compared with insecticide and fungicide nanocarrier studies, herbicide research clearly prioritizes reducing the non-target toxicity of the herbicides. Development of nanoparticle-based herbicides has also included a wider variety of nanoparticles. For example, montmorillonite clay layers coated with a pH dependent polymer [97], core-hollow shell manganese carbonate [98], nanosized tubular halloysite and platy kaolinite [99], amino-activated iron (II,III) oxide magnetic nanoparticles [100] and nanosized rice husks [101], have been used to date. 
Table 3. Summary of studies utilizing nanoparticles as carriers of herbicides.

\begin{tabular}{|c|c|c|c|c|}
\hline Herbicide (HRAC MoA Group ${ }^{\text {a) }}$ & Nanoparticle & Target Pest & Toxicity or Soil Leaching & Reference \\
\hline Paraquat (L) & Montmorillonite & - & - & [97] \\
\hline Paraquat (L) & Alginate/chitosan & - & Lara and Carvoeiro soil sorption & [102] \\
\hline Pendimethalin (D) & Manganese carbonate core-shell & - & - & [98] \\
\hline $\begin{array}{l}\text { Ametryn (C) } \\
\text { Atrazine (C) } \\
\text { Simazine (C) }\end{array}$ & Poly(E-caprolactone) & - & $\begin{array}{l}\text { Human blood cells } \\
\text { A. cepa }\end{array}$ & [103] \\
\hline $\begin{array}{l}\text { Simazine (C) } \\
\text { Atrazine (C) }\end{array}$ & Poly $(\varepsilon$-caprolactone $)$ coated in chitosan & - & - & [104] \\
\hline Paraquat (L) & Chitosan/tripolyphosphate & $\begin{array}{c}\text { Maize } \\
\text { Mustard (Brassica sp.) }\end{array}$ & $\begin{array}{c}\text { Chinese hamster ovary cells } \\
\text { A. cepa } \\
\text { Soil sorption }\end{array}$ & [105] \\
\hline Paraquat (L) & Chitosan/tripolyphosphate & - & $\begin{array}{l}\text { Microalga (P. subcapitata) } \\
\text { A. cepa }\end{array}$ & [106] \\
\hline $\begin{array}{l}\text { Atrazine (C) } \\
\text { Simazine (C) }\end{array}$ & SLN & R. raphanistrum & $\begin{array}{l}\text { Mouse fibroblast cells } \\
\text { Maize }\end{array}$ & [107] \\
\hline Amitrole (Q) & Tubular halloysite and platy kaolinite & - & - & [99] \\
\hline $\begin{array}{l}\text { Imazapic (B) and Imazapyr (B) } \\
\text { combined }\end{array}$ & Alginate/chitosanChitosan/tripolyphosphate & Black-jack (B. pilosa) & $\begin{array}{c}\text { Chinese hamster ovary cells } \\
\text { A. cepa } \\
\text { Soil biota }\end{array}$ & [108] \\
\hline Diuron (C) & Chitosan & E. crus-galli & Maize & [109] \\
\hline Glyphosate (M) & $\begin{array}{l}\text { Amino-activated aminopropyl silane } \\
\text { coated magnetic iron oxide }\end{array}$ & - & - & [100] \\
\hline $2,4-\mathrm{D}(\mathrm{I})$ & Nanosized rice husk & Maize & $\begin{array}{l}\text { Brassica Sp. } \\
\text { Soil sorption }\end{array}$ & [101] \\
\hline Clomazone (Q) & Chitosan/alginate & - & Liver bullfrog tadpoles (L. catesbeianus) & [110] \\
\hline Metolachlor (K) & Polymer & $\begin{array}{l}\text { Rice } \\
\text { D. sanguinalis } \\
\text { A. thaliana }\end{array}$ & Preosteoblast cell line (mammal) & [111] \\
\hline Paraquat (L) & SLN & & & \\
\hline Simazine (C) & Polymeric & - & C. elegans & [112] \\
\hline Atrazine $(C)$ & Chitosan/tripolyphosphate & & & \\
\hline Atrazine $(\mathrm{C})$ & Poly (lactic-co-glycolic Acid) & Potato plant & - & [113] \\
\hline
\end{tabular}

In this table, the tested herbicide with the HRAC MoA group and nanocarrier are listed. Experiments conducted against targeted pests or exploring environmental factors such as off-target toxicity and soil leaching are specified. Application onto desired crop plants, as per previous tables, was removed since not all herbicides are selective. If a non-target crop was tested [101,107,109], it has been included in the toxicity column. Of the 23 possible HRAC MoA groups, eight groups are represented; -, not tested; A. cepa, Allium cepa; A. thaliana, Arabidopsis thaliana; B. pilosa, Bidens pilosa; C. elegans, Caenorhabditis elegans; D. sanguinalis, Digitaria sanguinalis; E. crus-galli, Echinochloa crus-galli; HRAC, Herbicide Resistance Action Committee; L. catesbeianus, Lithobates catesbeianus; MoA, mode of action; NT, not tested; P. subcapitata, Pseudokirchneriella subcapitata; R. raphanistrum, Raphanus raphanistrum; SLN, solid lipid nanoparticle; ' HRAC MoA group key: Group B, inhibitors of acetolactate synthase (ALS inhibitors), acetohydroxyacid synthase (AHAS); Group C, inhibitors of photosynthesis at photosystem II (PS II inhibitors); Group D, inhibitors of microtubule assembly; Group I, disruptors of plant cell growth (Synthetic Auxins); Group K, inhibitors of cell division/inhibitors of very long chain fatty acids (VLCFA inhibitors); Group L, inhibitors of photosynthesis at photosystem I via electron diversion (PSI inhibitors); Group M, inhibitors of 5-enolpyruvyl shikimate-3 phosphate (EPSP) synthase; Group Q, bleachers: inhibitors of carotenoid biosynthesis unknown target. 
To reduce the toxicity of herbicides imazapic and imazapyr, both were loaded onto chitosan nanoparticles [108]. Similar effectiveness between nanoparticle-loaded and free herbicides was observed against the target weed Bidens pilosa. Toxicity was reduced in Allium cepa assays and Chinese hamster ovary cell cultures, compared to free herbicides. Maruyama et al. [108] also studied the effect on soil bacteria. Both nanoparticle-encapsulated and free herbicides did not affect the number of bacteria in the soil. However, the authors observed differences in the ratio of bacteria associated with the nitrogen cycle, and the nanoparticle-loaded herbicide group had the least impact.

In a different study, SLN loaded with both simazine and atrazine were found to be more effective at killing the target plant Raphanus raphanistrum when applied pre-emergence, and just as effective as the herbicide alone when applied post-emergence [107]. When tested on the non-target organism maize, no effect to the plant growth was observed. Furthermore, nanoparticle-loaded herbicides reduced toxicity ( $80 \%$ viability) against mouse fibroblast cells, compared to commercial herbicide (64\% viability). de Oliveira et al. [110] studied the effects of clomazone herbicide loaded onto chitosan-alginate nanoparticles in bullfrog tadpoles' liver (Lithobates catesbeianus) after acute exposure for $96 \mathrm{~h}$. Both free form and nanoparticle-loaded clomazone adversely affected the cells, and no protection by nanoparticles was observed.

Chidambaram [101] converted rice husk waste into nanosized particles, and loaded them with 2,4-D. They found that nanoparticle-loaded 2,4-D had better herbicidal activity than 2,4-D alone against the target plant (Brassica sp.) [101]. It was also found that the leaching effects in soil were reduced when the herbicide was bound to the nanosized rice husks. dos Santos Silva et al. [102] used paraquat loaded into alginate/chitosan to show reduced herbicide leaching in soil sorption studies, compared to paraquat alone. They also claimed a slower release rate that was $2 \mathrm{~h}$ longer than the herbicide alone. In another study, polymeric nanoparticles containing ametryn, atrazine, or simazine were slightly less toxic than herbicide alone, when subjected to genotoxicity studies using human lymphocyte and Allium cepa cell cultures [103]. Furthering the work, Grillo et al. [104] coated polymeric nanoparticles with different concentrations of chitosan to improve adhesion to target plants, but relied on the previous literature to prove that changing the bonds would provide better adhesion, as no adhesion studies were conducted. Grillo et al. [106] also studied the influence of aquatic humic substances, a complex of natural macromolecules in the environment, on paraquat-loaded chitosan. Allium cepa genotoxicity studies and ecotoxicity assays with the alga Pseudokirchneriella subcapitata showed that paraquat-loaded chitosan nanoparticles, in the presence of aquatic humic substances, decreased the toxicity, highlighting the need for more field trials in pesticide-loaded nanoparticle studies.

\section{Nanoparticles and RNAi for Plant Protection}

The discovery of the RNAi pathway has heralded new and innovating approaches for the management of pests and pathogens. RNAi, a conserved eukaryotic mechanism, is involved in the growth, development, and host defense against viruses and transposons, that can also be hijacked to target insects, fungi, viruses, and weeds [114-118]. Figure 3 describes the general mechanism of application of dsRNA to target pathogen RNA. In plants, RNAi is triggered by dsRNA, which is processed into small-interfering RNA (siRNA) by Dicer-like (DCL) enzymes. These siRNAs are incorporated into a RNA-induced silencing complex (RISC); siRNAs then direct the RISCs through base pairing to degrade the pathogen RNA, by preventing it from being used as a translation template [114]. Since its discovery, the RNAi pathway has emerged as a powerful tool to combat plant pests and pathogens by genetic modification $[119,120]$. However, genetically modified organisms are controversial and highly regulated in most countries; thus, research into new dsRNA delivery methods is being undertaken. 


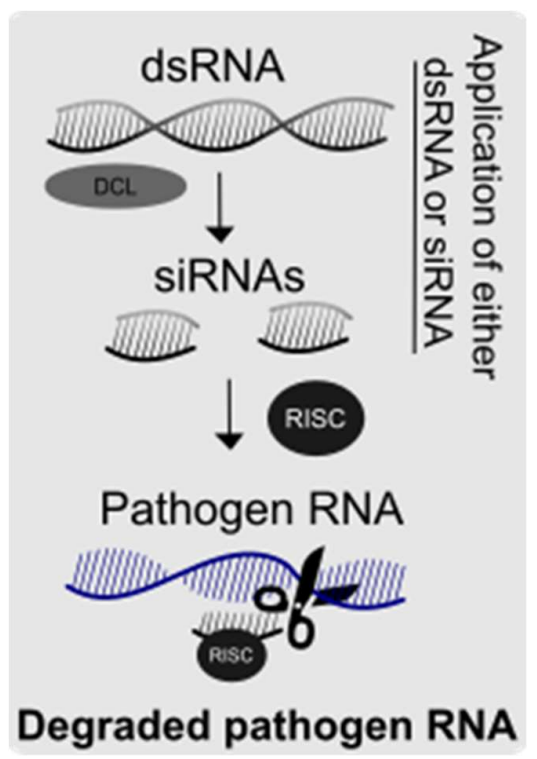

Figure 3. A brief overview of the RNAi pathway utilized for the application of RNAi-inducing molecules (dsRNA or siRNA) for gene silencing.

Topical application of dsRNA has emerged as a highly appealing alternative [119,120]. This method of application faces similar issues to pesticides, such as short longevity due to environmental degradation, and difficulties with site-specific uptake by the targeted pest. To date, nanoparticles acting as carriers of RNAi-inducing molecules have been targeted against viruses [32], used with honeybees as a model organism for DNA methylation and alternative splicing [121], and targeted against aphids [122] and mosquitoes [123,124]. Mitter et al. (2017), successfully afforded viral protection against cucumber mosaic virus (CMV) and pepper mild mottle virus (PMMoV) using plants sprayed with dsRNA loaded onto LDH nanoparticles, called BioClay. Significantly, a single spray of BioClay protected plants for 20 days after application on sprayed, and on newly emerged, unsprayed leaves, while plants sprayed with naked dsRNA succumbed to viral infection. Jiang et al. (2014) made the only other report of nanoparticle-facilitated plant uptake of dsRNA through the root tip to induce gene silencing of two endogenous Arabidopsis genes.

Li-Byarlay et al. [121] used siRNA loaded onto perfluorocarbon nanoparticles to study DNA methylation in honeybees. Although honeybees are considered a non-target insect, this study shows that the aerosol delivery of siRNA-loaded perfluorocarbon was achieved. This initial research conducted by Li-Byarlay et al. [121] provided the stepping stone needed to develop the perfluorocarbon-siRNA nanotechnology to target three different aphid species; Acyrthosiphon pisum, Aphis glycines, and Schizaphis graminum [122]. It was observed that the nanoparticle-loaded siRNA had a significantly higher gene knockdown than siRNA alone.

Further research is limited to targeting mosquitoes for human disease control; however, it has the potential to be applied against agricultural pests. Based on four studies, chitosan nanoparticles were loaded with dsRNA targeted to the African malaria vector Anopheles gambiae and/or the dengue and yellow fever vector Aedes aegypti, with successful knockdown of the targeted genes [71,123-125]. Comparative analysis was conducted between chitosan, carbon quantum dot, and silica nanoparticles as carriers of dsRNA against $A$. aegypti larvae [123]. Das et al. [123] found that carbon quantum dot coated in polyethyleneimine was the most efficient for dsRNA delivery and mosquito mortality. Each of these reports shows the potential of nanoparticle-facilitated, topical application of RNAi, due to its potential to target a wide range of fugal pathogens [126,127], insect pests [128,129], and plant viruses [32] with RNAi. Although exogenous application of RNAi-inducing molecules for crop protection holds strong appeal over pesticides, due to its reduced toxicity, topical application of RNAi still faces its own hurdles [120]. 


\section{Conclusion and Future Outlook}

Nanotechnology can provide solutions for agricultural applications and has the potential to revolutionize the existing technologies used in pest management. Development of nanopesticides can offer unprecedented advantages like (i) improved solubility of poorly water-soluble pesticides, (ii) increased bioavailability and efficacy of pesticides when loaded onto nanoparticles and reduced pesticide toxicity, (iii) enhanced shelf-life and controlled delivery of actives, (iv) target-specific delivery of the active molecules and $\mathrm{pH}$ dependent release, (v) smart delivery of RNAi molecules for disease management, (vi) nanoparticles as carriers to slow down degradation of active molecules and improve the formulations' UV stability and rain-fastness, (vii) nanopesticides to improve the selective toxicity and overcome pesticide resistance.

It is clear from the above discussion that nanopesticides represent an attractive advancement, owing to their potential advantages for the environment and human health. However, nanotechnology in the agricultural sector is not reaching the market. Most of the developed nanoparticle-based pesticides are at the very early stage of development; hence, the efficacy and toxicity of the nanopesticides on soil and environment needs be studied in more detail. Of the many studies of pesticides loaded onto nanoparticles, only two of them have conducted field trials; chlorfenapyr loaded onto silica nanoparticles with additional emulsions was applied to Brassica chinese [44], and imidacloprid loaded onto sodium alginate nanoparticles [48]. Another issue with the early stages of research on nanoparticles in plant protection is the current lack of long-term trials. Only a few studies have included extended time trials in their studies; for example, Mitter et al. [32] tested an $\mathrm{RNAi} /$ nanoparticle topical delivery platform called BioClay to protect plants against viruses 20 days post-spray application, Zhao et al. [90] studied the pesticide levels over 48 days post-application of their developed nanoformulation, Yang et al. [41] tested for insecticidal activity for 5 months after application of their formulation on stored grain, and Jenne et al. [62] studied azadirachtin in either zinc oxide or chitosan nanoparticles in a jar of ground nuts infested with the groundnut bruchid insect over 180 days.

Nanopesticides are an emerging technological advancement where, in relation to pesticide use, there is a lack of a clear definition of what is, and what is not a nanopesticide, by regulatory bodies [130]. Kookana et al. [130], in their review, have discussed in-depth that, unlike conventional pesticides, the effects of nanopesticides may be dependent on the uptake, bioavailability, concentration, and toxicity of the nanoparticles, as well as the ratio of the active bound to them. Also, there is limited data concerning the issue of pesticide resistance and how the addition of nanoparticles could conceivably reduce its incidence. Without using the comprehensive analytical tools, regulatory requirements for risk assessment cannot be generated. Only eight out of 30 insecticide MoA groups, 10 out of 49 fungicide FRAC groups, and eight out of 23 herbicide HRAC groups have been loaded onto nanoparticles and tested, to date. Current pesticide application requires rotation between groups to prevent pesticide resistance and a broad range of nanopesticides would need to be available for future commercial applications. Factors to consider in regards to developing nanopesticides are limited information known about the fate and safety aspects of nanopesticides in field and long-term trials, their high production cost, the requirement for high volumes, legislative uncertainties, and public opinion [131-133]. Integrating the new tools and techniques to generate robust data for analysis, characterization, and risk assessment might be the keys to getting approval from the regulatory bodies.

In conclusion, material scientists and biologists need to work closely and bring in complementary expertise from various fields, in order to have a deeper understanding of the fundamental interaction mechanisms in a complex bio-nano system. A comprehensive understanding about the structural properties of the nanoparticles, such as morphology, size, functional groups, and active adsorption/loading capacity, may provide a useful guide as a starting point for the rational choice of suitable nanoparticles. It is also important to select a reliable and reproducible system to conduct biocompatibility and efficacy studies at the cell, organism, and pest-host ecosystem levels, aiming for as-close-to field conditions as possible. The research and development landscape for agricultural 
nanotechnology is very promising, as the possibilities offered by nanoparticles for developing efficient products are being actively explored. The authors believe that multidisciplinary and collaborative research will provide a concrete platform to bring the applications of nanotechnology for plant protection a reality.

Author Contributions: E.A.W., A.H., and K.T.M. wrote the manuscript. All authors edited the manuscript and approved the final draft.

Funding: E.A.W. Ph.D. programme with N.M. is supported by a scholarship from the University of Queensland. A.H. was supported by WSU and by the grant to A.H. by the University Grants Commission of India, No F. 5-4/2016(IC).

Acknowledgments: E.A.W., K.T.M. and N.M. would like to thank the support of The University of Queensland and Queensland Alliance of Agriculture and Food Innovation (QAAFI).

Conflicts of Interest: The authors declare that the research was conducted in the absence of any commercial or financial relationships that could be construed as a potential conflict of interest.

\section{References}

1. Flood, J. The importance of plant health to food security. Food Secur. 2010, 2, 215-231. [CrossRef]

2. Stephenson, G.R. Pesticide Use and World Food Production: Risks and Benefits; ACS Publications: Washington, DC, USA, 2003.

3. Ghormade, V.; Deshpande, M.V.; Paknikar, K.M. Perspectives for nano-biotechnology enabled protection and nutrition of plants. Biotechnol. Adv. 2011, 29, 792-803. [CrossRef] [PubMed]

4. Sinha, K.; Ghosh, J.; Sil, P.C. 2-New pesticides: A cutting-edge view of contributions from nanotechnology for the development of sustainable agricultural pest control A2-Grumezescu, Alexandru Mihai. In New Pesticides and Soil Sensors; Academic Press: Cambridge, MA, USA, 2017.

5. Balaure, P.C.; Gudovan, D.; Gudovan, I. Nanopesticides: A new paradigm in crop protection. New Pestic. Soil Sens. 2017, 129-192. [CrossRef]

6. Hayles, J.; Johnson, L.; Worthley, C.; Losic, D. Nanopesticides: A review of current research and perspectives. New Pestic. Soil Sens. 2017, 193-225. [CrossRef]

7. Khandelwal, N.; Barbole, R.S.; Banerjee, S.S.; Chate, G.P.; Biradar, A.V.; Khandare, J.J.; Giri, A.P. Budding trends in integrated pest management using advanced micro-and nano-materials: Challenges and perspectives. J. Environ. Manag. 2016, 184, 157-169. [CrossRef] [PubMed]

8. Yang, W.; Peters, J.I.; Williams, R.O. Inhaled nanoparticles-A current review. Int. J. Pharm. 2008, 356, 239-247. [CrossRef] [PubMed]

9. Kah, M.; Hofmann, T. Nanopesticide research: Current trends and future priorities. Environ. Int. 2014, 63, 224-235. [CrossRef] [PubMed]

10. Gogos, A.; Knauer, K.; Bucheli, T.D. Nanomaterials in plant protection and fertilization: Current state, foreseen applications, and research priorities. J. Agric. Food Chem. 2012, 60, 9781-9792. [CrossRef] [PubMed]

11. Kim, D.Y.; Kadam, A.; Shinde, S.; Saratale, R.G.; Patra, J.; Ghodake, G. Recent developments in nanotechnology transforming the agricultural sector: A transition replete with opportunities. J. Sci. Food Agric. 2018, 98, 849-864. [CrossRef] [PubMed]

12. Mishra, S.; Singh, H. Biosynthesized silver nanoparticles as a nanoweapon against phytopathogens: Exploring their scope and potential in agriculture. Appl. Microbiol. Biotechnol. 2015, 99, 1097-1107. [CrossRef] [PubMed]

13. Sadeghi, R.; Rodriguez, R.J.; Yao, Y.; Kokini, J.L. Advances in nanotechnology as they pertain to food and agriculture: Benefits and risks. Annu. Rev. Food Sci. Technol. 2017, 8, 467-492. [CrossRef] [PubMed]

14. Malerba, M.; Cerana, R. Chitosan effects on plant systems. Int. J. Mol. Sci. 2016, 17, 996. [CrossRef] [PubMed]

15. Rafique, M.; Sadaf, I.; Rafique, M.S.; Tahir, M.B. A review on green synthesis of silver nanoparticles and their applications. Artif. Cells Nanomed. Biotechnol. 2017, 45, 1272-1291. [CrossRef] [PubMed]

16. Krishnaraj, C.; Ramachandran, R.; Mohan, K.; Kalaichelvan, P. Optimization for rapid synthesis of silver nanoparticles and its effect on phytopathogenic fungi. Spectrochim. Acta Part A Mol. Biomol. Spectrosc. 2012, 93, 95-99. [CrossRef] [PubMed]

17. Jain, D.; Kothari, S. Green synthesis of silver nanoparticles and their application in plant virus inhibition. J. Mycol. Plant Pathol. 2014, 44, 21. 
18. Elbeshehy, E.K.F.; Elazzazy, A.M.; Aggelis, G. Silver nanoparticles synthesis mediated by new isolates of Bacillus spp., nanoparticle characterization and their activity against Bean Yellow Mosaic Virus and human pathogens. Front. Microbiol. 2015, 6, 453. [CrossRef] [PubMed]

19. Alkubaisi, N.A.O.; Aref, N.M.M.A.; Hendi, A.A. Method of Inhibiting Plant Virus Using Gold Nanoparticles. US Patents US9198434B1, 1 December 2015.

20. Cota-Arriola, O.; Onofre Cortez-Rocha, M.; Burgos-Hernández, A.; Marina Ezquerra-Brauer, J.; Plascencia-Jatomea, M. Controlled release matrices and micro/nanoparticles of chitosan with antimicrobial potential: Development of new strategies for microbial control in agriculture. J. Sci. Food Agric. 2013, 93, 1525-1536. [CrossRef] [PubMed]

21. Kochkina, Z.; Pospeshny, G.; Chirkov, S. Inhibition by chitosan of productive infection of T-series bacteriophages in the Escherichia coli culture. Mikrobiologiia 1994, 64, 211-215.

22. Pospieszny, H.; Chirkov, S.; Atabekov, J. Induction of antiviral resistance in plants by chitosan. Plant Sci. 1991, 79, 63-68. [CrossRef]

23. Chirkov, S. The antiviral activity of chitosan (review). Appl. Biochem. Microbiol. 2002, 38, 1-8. [CrossRef]

24. Kashyap, P.L.; Xiang, X.; Heiden, P. Chitosan nanoparticle based delivery systems for sustainable agriculture. Int. J. Boil. Macromol. 2015, 77, 36-51. [CrossRef] [PubMed]

25. Mody, V.V.; Cox, A.; Shah, S.; Singh, A.; Bevins, W.; Parihar, H. Magnetic nanoparticle drug delivery systems for targeting tumor. Appl. Nanosci. 2014, 4, 385-392. [CrossRef]

26. Barik, T.; Sahu, B.; Swain, V. Nanosilica-from medicine to pest control. Parasitol. Res. 2008, 103, $253-258$. [CrossRef] [PubMed]

27. Li, M.; Huang, Q.; Wu, Y. A novel chitosan-poly (lactide) copolymer and its submicron particles as imidacloprid carriers. Pest Manag. Sci. 2011, 67, 831-836. [CrossRef] [PubMed]

28. Ekambaram, P.; Sathali, A.A.H.; Priyanka, K. Solid lipid nanoparticles: A review. Sci. Rev. Chem. Commun. 2012, 2, 80-102.

29. Borel, T.; Sabliov, C. Nanodelivery of bioactive components for food applications: Types of delivery systems, properties, and their effect on ADME profiles and toxicity of nanoparticles. Annu. Rev. Food Sci. Technol. 2014, 5, 197-213. [CrossRef] [PubMed]

30. Tamjidi, F.; Shahedi, M.; Varshosaz, J.; Nasirpour, A. Nanostructured lipid carriers (NLC): A potential delivery system for bioactive food molecules. Innov. Food Sci. Emerg. Technol. 2013, 19, 29-43. [CrossRef]

31. Xu, Z.P.; Stevenson, G.S.; Lu, C.-Q.; Lu, G.Q.; Bartlett, P.F.; Gray, P.P. Stable suspension of layered double hydroxide nanoparticles in aqueous solution. J. Am. Chem. Soc. 2006, 128, 36-37. [CrossRef] [PubMed]

32. Mitter, N.; Worrall, E.A.; Robinson, K.E.; Li, P.; Jain, R.G.; Taochy, C.; Fletcher, S.J.; Carroll, B.J.; Lu, G.; Xu, Z.P. Clay nanosheets for topical delivery of RNAi for sustained protection against plant viruses. Nat. Plants 2017, 3, 16207. [CrossRef] [PubMed]

33. Bao, W.; Wang, J.; Wang, Q.; O'Hare, D.; Wan, Y. Layered Double Hydroxide Nanotransporter for Molecule Delivery to Intact Plant Cells. Sci. Rep. 2016, 6. [CrossRef] [PubMed]

34. Sparks, T.C.; Nauen, R. IRAC: Mode of action classification and insecticide resistance management. Pestic. Biochem. Physiol. 2015, 121, 122-128. [CrossRef] [PubMed]

35. Kuck, K.-H.; Leadbeater, A.; Gisi, U. FRAC Mode of Action Classification and Resistance Risk of Fungicides. In Modern Crop Protection Compounds; Wiley-VCH Verlag GmbH \& Co. KGaA: Weinheim, Germany, 2012; pp. 539-557.

36. Liu, Y.; Yan, L.; Heiden, P.; Laks, P. Use of nanoparticles for controlled release of biocides in solid wood. J. Appl. Polym. Sci. 2001, 79, 458-465. [CrossRef]

37. Lai, F.; Wissing, S.A.; Müller, R.H.; Fadda, A.M. Artemisia arborescens L essential oil-loaded solid lipid nanoparticles for potential agricultural application: Preparation and characterization. AAPS PharmSciTech 2006, 7, E10. [CrossRef] [PubMed]

38. Wen, L.X.; Li, Z.Z.; Zou, H.K.; Liu, A.Q.; Chen, J.F. Controlled release of avermectin from porous hollow silica nanoparticles. Pest Manag. Sci. 2005, 61, 583-590. [CrossRef] [PubMed]

39. Li, Z.-Z.; Xu, S.-A.; Wen, L.-X.; Liu, F.; Liu, A.-Q.; Wang, Q.; Sun, H.-Y.; Yu, W.; Chen, J.-F. Controlled release of avermectin from porous hollow silica nanoparticles: Influence of shell thickness on loading efficiency, UV-shielding property and release. J. Control. Release 2006, 111, 81-88. [CrossRef] [PubMed] 
40. Li, Z.Z.; Chen, J.F.; Liu, F.; Liu, A.Q.; Wang, Q.; Sun, H.Y.; Wen, L.X. Study of UV-shielding properties of novel porous hollow silica nanoparticle carriers for avermectin. Pest Manag. Sci. 2007, 63, 241-246. [CrossRef] [PubMed]

41. Yang, F.-L.; Li, X.-G.; Zhu, F.; Lei, C.-L. Structural characterization of nanoparticles loaded with garlic essential oil and their insecticidal activity against Tribolium castaneum (Herbst)(Coleoptera: Tenebrionidae). J. Agric. Food Chem. 2009, 57, 10156-10162. [CrossRef] [PubMed]

42. Nguyen, H.M.; Hwang, I.C.; Park, J.W.; Park, H.J. Photoprotection for deltamethrin using chitosan-coated beeswax solid lipid nanoparticles. Pest Manag. Sci. 2012, 68, 1062-1068. [CrossRef] [PubMed]

43. Nguyen, H.; Hwang, I.; Park, J.; Park, H. Enhanced payload and photo-protection for pesticides using nanostructured lipid carriers with corn oil as liquid lipid. J. Microencapsul. 2012, 29, 596-604. [CrossRef] [PubMed]

44. Song, M.-R.; Cui, S.-M.; Gao, F.; Liu, Y.-R.; Fan, C.-L.; Lei, T.-Q.; Liu, D.-C. Dispersible silica nanoparticles as carrier for enhanced bioactivity of chlorfenapyr. J. Pestic. Sci. 2012, 37, 258-260. [CrossRef]

45. Feng, B.-H.; Peng, L.-F. Synthesis and characterization of carboxymethyl chitosan carrying ricinoleic functions as an emulsifier for azadirachtin. Carbohydr. Polym. 2012, 88, 576-582. [CrossRef]

46. Zhang, J.; Li, M.; Fan, T.; Xu, Q.; Wu, Y.; Chen, C.; Huang, Q. Construction of novel amphiphilic chitosan copolymer nanoparticles for chlorpyrifos delivery. J. Polym. Res. 2013, 20, 107. [CrossRef]

47. Lu, W.; Lu, M.L.; Zhang, Q.P.; Tian, Y.Q.; Zhang, Z.X.; Xu, H.H. Octahydrogenated retinoic acid-conjugated glycol chitosan nanoparticles as a novel carrier of azadirachtin: Synthesis, characterization, and in vitro evaluation. J. Polym. Sci. Part A Polym. Chem. 2013, 51, 3932-3940. [CrossRef]

48. Kumar, S.; Bhanjana, G.; Sharma, A.; Sidhu, M.; Dilbaghi, N. Synthesis, characterization and on field evaluation of pesticide loaded sodium alginate nanoparticles. Carbohydr. Polym. 2014, 101, 1061-1067. [CrossRef] [PubMed]

49. Rani, P.U.; Madhusudhanamurthy, J.; Sreedhar, B. Dynamic adsorption of $\alpha$-pinene and linalool on silica nanoparticles for enhanced antifeedant activity against agricultural pests. J. Pest Sci. 2014, 87, 191-200. [CrossRef]

50. Wang, Y.; Cui, H.; Sun, C.; Zhao, X.; Cui, B. Construction and evaluation of controlled-release delivery system of Abamectin using porous silica nanoparticles as carriers. Nanoscale Res. Lett. 2014, 9, 2490. [CrossRef] [PubMed]

51. Nguyen, T.N.Q.; Le, V.A.; Hua, Q.C.; Nguyen, T.T. Enhancing Insecticide Activity of Anacardic Acid by Intercalating it into $\mathrm{MgAl}$ Layered Double Hydroxides Nanoparticles; Institut für Abfallwirtschaft und Altlasten, Fakultät Umweltwissenschaften, Technische Universität Dresden: Dresden, Germany, 2015.

52. Wibowo, D.; Zhao, C.-X.; Peters, B.C.; Middelberg, A.P. Sustained release of fipronil insecticide in vitro and in vivo from biocompatible silica nanocapsules. J. Agric. Food Chem. 2014, 62, 12504-12511. [CrossRef] [PubMed]

53. Jia, X.; Sheng, W.-B.; Li, W.; Tong, Y.-B.; Liu, Z.-Y.; Zhou, F. Adhesive polydopamine coated avermectin microcapsules for prolonging foliar pesticide retention. ACS Appl. Mater. Interfaces 2014, 6, 19552-19558. [CrossRef] [PubMed]

54. Sheng, W.-B.; Li, W.; Zhang, G.-X.; Tong, Y.-B.; Liu, Z.-Y.; Jia, X. Study on the UV-shielding and controlled-release properties of a polydopamine coating for avermectin. New J. Chem. 2015, 39, 2752-2757. [CrossRef]

55. Liu, X.; He, B.; Xu, Z.; Yin, M.; Yang, W.; Zhang, H.; Cao, J.; Shen, J. A functionalized fluorescent dendrimer as a pesticide nanocarrier: Application in pest control. Nanoscale 2015, 7, 445-449. [CrossRef] [PubMed]

56. Meredith, A.N.; Harper, B.; Harper, S.L. The influence of size on the toxicity of an encapsulated pesticide: A comparison of micron-and nano-sized capsules. Environ. Int. 2016, 86, 68-74. [CrossRef] [PubMed]

57. Glinski, A.; Liebel, S.; Pelletier, È.; Voigt, C.L.; Randi, M.A.F.; Campos, S.X.; Oliveira Ribeiro, C.A.; Filipak Neto, F. Toxicological interactions of silver nanoparticles and organochlorine pesticides in mouse peritoneal macrophages. Toxicol. Mech. Methods 2016, 26, 251-259. [CrossRef] [PubMed]

58. Suresh, U.; Murugan, K.; Panneerselvam, C.; Rajaganesh, R.; Roni, M.; Al-Aoh, H.A.N.; Trivedi, S.; Rehman, H.; Kumar, S.; Higuchi, A. Suaeda maritima-based herbal coils and green nanoparticles as potential biopesticides against the dengue vector Aedes aegypti and the tobacco cutworm Spodoptera litura. Physiol. Mol. Plant Pathol. 2018, 101, 225-235. [CrossRef] 
59. Paulraj, M.G.; Ignacimuthu, S.; Gandhi, M.R.; Shajahan, A.; Ganesan, P.; Packiam, S.M.; Al-Dhabi, N.A. Comparative studies of Tripolyphosphate and Glutaraldehyde cross-linked chitosan-botanical pesticide nanoparticles and their agricultural applications. Int. J. Boil. Macromol. 2017, 104 Pt B, 1813-1819. [CrossRef]

60. Liang, J.; Yu, M.; Guo, L.; Cui, B.; Zhao, X.; Sun, C.; Wang, Y.; Liu, G.; Cui, H.; Zeng, Z. Bioinspired Development of P (St-MAA)-Avermectin Nanoparticles with High Affinity for Foliage To Enhance Folia Retention. J. Agric. Food Chem. 2018, 66, 6578-6584. [CrossRef] [PubMed]

61. Zhang, H.; Qin, H.; Li, L.; Zhou, X.; Wang, W.; Kan, C. Preparation and characterization of controlled-release avermectin/castor oil-based polyurethane nanoemulsions. J. Agric. Food Chem. 2018, 66, 6552-6560. [CrossRef] [PubMed]

62. Jenne, M.; Kambham, M.; Tollamadugu, N.P.; Karanam, H.P.; Tirupati, M.K.; Balam, R.R.; Shameer, S.; Yagireddy, M. The use of slow releasing nanoparticle encapsulated Azadirachtin formulations for the management ofCaryedon serratusO.(groundnut bruchid). IET Nanobiotechnol. 2018, 12, 963-967. [CrossRef] [PubMed]

63. Campos, E.V.; Proença, P.L.; Oliveira, J.L.; Melville, C.C.; Vechia, J.F.; Andrade, D.J.; Fraceto, L.F. Chitosan nanoparticles functionalized with $\beta$-cyclodextrin: A promising carrier for botanical pesticides. Sci. Rep. 2018, 8, 2067. [CrossRef] [PubMed]

64. De Oliveira, J.L.; Campos, E.V.R.; Pereira, A.E.S.; Nunes, L.E.; da Silva, C.C.; Pasquoto, T.; Lima, R.; Smaniotto, G.; Polanczyk, R.A.; Fraceto, L.F. Geraniol encapsulated in chitosan/gum arabic nanoparticles: A promising system for pest management in sustainable agriculture. J. Agric. Food Chem. 2018, 66, 5325-5334. [CrossRef] [PubMed]

65. Ahmadi, Z.; Saber, M.; Akbari, A.; Mahdavinia, G.R. Encapsulation of Satureja hortensis L. (Lamiaceae) in chitosan/TPP nanoparticles with enhanced acaricide activity against Tetranychus urticae Koch (Acari: Tetranychidae). Ecotoxicol. Environ. Saf. 2018, 161, 111-119. [CrossRef] [PubMed]

66. Oliveira, J.L.D.; Campos, E.N.V.; Pereira, A.E.; Pasquoto, T.; Lima, R.; Grillo, R.; Andrade, D.J.D.; Santos, F.A.D.; Fraceto, L.F. Zein nanoparticles as eco-friendly carrier systems for botanical repellents aiming sustainable agriculture. J. Agric. Food Chem. 2018, 66, 1330-1340. [CrossRef] [PubMed]

67. Yang, Y.; Cheng, J.; Garamus, V.M.; Li, N.; Zou, A. Preparation of an environmentally friendly formulation of the insecticide nicotine hydrochloride through encapsulation in chitosan/tripolyphosphate nanoparticles. J. Agric. Food Chem. 2018, 66, 1067-1074. [CrossRef] [PubMed]

68. Wang, X.; Ma, X.; Huang, P.; Wang, J.; Du, T.; Du, X.; Lu, X. Magnetic Cu-MOFs embedded within graphene oxide nanocomposites for enhanced preconcentration of benzenoid-containing insecticides. Talanta 2018, 181, 112-117. [CrossRef] [PubMed]

69. Campos, E.V.; Proença, P.L.; Oliveira, J.L.; Pereira, A.E.; Ribeiro, L.N.; Fernandes, F.O.; Gonçalves, K.C.; Polanczyk, R.A.; Pasquoto-Stigliani, T.; Lima, R. Carvacrol and linalool co-loaded in $\beta$-cyclodextrin-grafted chitosan nanoparticles as sustainable biopesticide aiming pest control. Sci. Rep. 2018, 8, 7623. [CrossRef] [PubMed]

70. Kaziem, A.E.; Gao, Y.; Zhang, Y.; Qin, X.; Xiao, Y.; Zhang, Y.; You, H.; Li, J.; He, S. $\alpha$-Amylase triggered carriers based on cyclodextrin anchored hollow mesoporous silica for enhancing insecticidal activity of avermectin against Plutella xylostella. J. Hazard. Mater. 2018, 359, 213-221. [CrossRef] [PubMed]

71. Kumar, D.R.; Kumar, P.S.; Gandhi, M.R.; Al-Dhabi, N.A.; Paulraj, M.G.; Ignacimuthu, S. Delivery of chitosan/dsRNA nanoparticles for silencing of wing development vestigial (vg) gene in Aedes aegypti mosquitoes. Int. J. Boil. Macromol. 2016, 86, 89-95. [CrossRef] [PubMed]

72. Liu, Y.; Laks, P.; Heiden, P. Controlled release of biocides in solid wood. III. Preparation and characterization of surfactant-free nanoparticles. J. Appl. Polym. Sci. 2002, 86, 615-621. [CrossRef]

73. Liu, Y.; Laks, P.; Heiden, P. Controlled release of biocides in solid wood. I. Efficacy against brown rot wood decay fungus (Gloeophyllum trabeum). J. Appl. Polym. Sci. 2002, 86, 596-607. [CrossRef]

74. Liu, Y.; Laks, P.; Heiden, P. Controlled release of biocides in solid wood. II. Efficacy against Trametes versicolor and Gloeophyllum trabeum wood decay fungi. J. Appl. Polym. Sci. 2002, 86, 608-614. [CrossRef]

75. Hatfaludi, T.; Liska, M.; Zellinger, D.; Ousman, J.P.; Szostak, M.; Jalava, K.; Lubitz, W. Bacterial ghost technology for pesticide delivery. J. Agric. Food Chem. 2004, 52, 5627-5634. [CrossRef] [PubMed]

76. Liu, F.; Wen, L.-X.; Li, Z.-Z.; Yu, W.; Sun, H.-Y.; Chen, J.-F. Porous hollow silica nanoparticles as controlled delivery system for water-soluble pesticide. Mater. Res. Bull. 2006, 41, 2268-2275. [CrossRef] 
77. Qian, K.; Shi, T.; Tang, T.; Zhang, S.; Liu, X.; Cao, Y. Preparation and characterization of nano-sized calcium carbonate as controlled release pesticide carrier for validamycin against Rhizoctonia solani. Microchim. Acta 2011, 173, 51-57. [CrossRef]

78. Qian, K.; Shi, T.; He, S.; Luo, L.; Cao, Y. Release kinetics of tebuconazole from porous hollow silica nanospheres prepared by miniemulsion method. Microporous Mesoporous Mater. 2013, 169, 1-6. [CrossRef]

79. Dar, J.; Soytong, K. Construction and characterization of copolymer nanomaterials loaded with bioactive compounds from Chaetomium species. J. Agric. Technol. 2014, 10, 823-831.

80. Wanyika, H. Sustained release of fungicide metalaxyl by mesoporous silica nanospheres. J. Nanopart. Res. 2013, 15, 1831. [CrossRef]

81. Xu, L.; Cao, L.-D.; Li, F.-M.; Wang, X.-J.; Huang, Q.-L. Utilization of chitosan-lactide copolymer nanoparticles as controlled release pesticide carrier for pyraclostrobin against Colletotrichum gossypii Southw. J. Dispers. Sci. Technol. 2014, 35, 544-550. [CrossRef]

82. Mei, X.D.; Liang, Y.H.; Zhang, T.; Ning, J.; Wang, Z.Y. An amphiphilic chitosan-polylactide graft copolymer and its nanoparticles as fungicide carriers. Proc. Adv. Mater. Res. 2014, 1051, 21-28. [CrossRef]

83. Campos, E.V.R.; De Oliveira, J.L.; Da Silva, C.M.G.; Pascoli, M.; Pasquoto, T.; Lima, R.; Abhilash, P.; Fraceto, L.F. Polymeric and solid lipid nanoparticles for sustained release of carbendazim and tebuconazole in agricultural applications. Sci. Rep. 2015, 5, 13809. [CrossRef] [PubMed]

84. Janatova, A.; Bernardos, A.; Smid, J.; Frankova, A.; Lhotka, M.; Kourimská, L.; Pulkrabek, J.; Kloucek, P. Long-term antifungal activity of volatile essential oil components released from mesoporous silica materials. Ind. Crop. Prod. 2015, 67, 216-220. [CrossRef]

85. Ilk, S.; Saglam, N.; Özgen, M. Kaempferol loaded lecithin/chitosan nanoparticles: Preparation, characterization, and their potential applications as a sustainable antifungal agent. Artif. Cells Nanomed. Biotechnol. 2017, 45, 907-916. [CrossRef] [PubMed]

86. Nasseri, M.; Golmohammadzadeh, S.; Arouiee, H.; Jaafari, M.R.; Neamati, H. Antifungal activity of Zataria multiflora essential oil-loaded solid lipid nanoparticles in-vitro condition. Iran. J. Basic Med. Sci. 2016, 19, 1231-1237. [PubMed]

87. Hou, R.; Zhang, Z.; Pang, S.; Yang, T.; Clark, J.M.; He, L. Alteration of the nonsystemic behavior of the pesticide ferbam on tea leaves by engineered gold nanoparticles. Environ. Sci. Technol. 2016, 50, 6216-6223. [CrossRef] [PubMed]

88. Cao, L.; Zhang, H.; Cao, C.; Zhang, J.; Li, F.; Huang, Q. Quaternized chitosan-capped mesoporous silica nanoparticles as nanocarriers for controlled pesticide release. Nanomaterials 2016, 6, 126. [CrossRef] [PubMed]

89. Kumar, S.; Kumar, D.; Dilbaghi, N. Preparation, characterization, and bio-efficacy evaluation of controlled release carbendazim-loaded polymeric nanoparticles. Environ. Sci. Pollut. Res. 2017, 24, 926-937.

90. Zhao, P.; Cao, L.; Ma, D.; Zhou, Z.; Huang, Q.; Pan, C. Synthesis of Pyrimethanil-Loaded Mesoporous Silica Nanoparticles and Its Distribution and Dissipation in Cucumber Plants. Molecules 2017, 22, 817. [CrossRef] [PubMed]

91. Zhao, P.; Cao, L.; Ma, D.; Zhou, Z.; Huang, Q.; Pan, C. Translocation, distribution and degradation of prochloraz-loaded mesoporous silica nanoparticles in cucumber plants. Nanoscale 2018, 10, 1798-1806. [CrossRef] [PubMed]

92. Hasheminejad, N.; Khodaiyan, F.; Safari, M. Improving the antifungal activity of clove essential oil encapsulated by chitosan nanoparticles. Food Chem. 2019, 275, 113-122. [CrossRef]

93. Huang, W.; Wang, C.; Duan, H.; Bi, Y.; Wu, D.; Du, J.; Yu, H. Synergistic Antifungal Effect of Biosynthesized Silver Nanoparticles Combined with Fungicides. Int. J. Agric. Biol. 2018, 20, 1225-1229.

94. Kalagatur, N.K.; Ghosh, O.S.N.; Sundararaj, N.; Mudili, V. Antifungal activity of chitosan nanoparticles encapsulated with Cymbopogon martinii essential oil on plant pathogenic fungi Fusarium graminearum. Front. Pharmacol. 2018, 9, 610. [CrossRef] [PubMed]

95. Wang, Y.; Li, C.; Wang, Y.; Zhang, Y.; Li, X. Compound Pesticide Controlled Release System Based on the Mixture of poly (butylene succinate) and PLA. J. Microencapsul. 2018, 1-33. [CrossRef] [PubMed]

96. Cao, L.; Zhang, H.; Zhou, Z.; Xu, C.; Shan, Y.; Lin, Y.; Huang, Q. Fluorophore-free luminescent double-shelled hollow mesoporous silica nanoparticles as pesticide delivery vehicles. Nanoscale 2018, 10, 20354-20365. [CrossRef] [PubMed]

97. Han, Y.-S.; Lee, S.-Y.; Yang, J.-H.; Hwang, H.S.; Park, I. Paraquat release control using intercalated montmorillonite compounds. J. Phys. Chem. Solids 2010, 71, 460-463. [CrossRef] 
98. Kanimozhi, V.; Chinnamuthu, C. Engineering core/hallow shell nanomaterials to load herbicide active ingredient for controlled release. Res. J. Nanosci. Nanotechnol. 2012, 2, 58-69. [CrossRef]

99. Tan, D.; Yuan, P.; Annabi-Bergaya, F.; Dong, F.; Liu, D.; He, H. A comparative study of tubular halloysite and platy kaolinite as carriers for the loading and release of the herbicide amitrole. Appl. Clay Sci. 2015, 114, 190-196. [CrossRef]

100. Viirlaid, E.; Riiberg, R.; Mäeorg, U.; Rinken, T. Glyphosate attachment on aminoactivated carriers for sample stabilization and concentration. Agron. Res. 2009, 13, 1152-1159.

101. Chidambaram, R. Application of rice husk nanosorbents containing 2, 4-dichlorophenoxyacetic acid herbicide to control weeds and reduce leaching from soil. J. Taiwan Inst. Chem. Eng. 2016, 63, 318-326.

102. dos Santos Silva, M.; Cocenza, D.S.; Grillo, R.; de Melo, N.F.S.; Tonello, P.S.; de Oliveira, L.C.; Cassimiro, D.L.; Rosa, A.H.; Fraceto, L.F. Paraquat-loaded alginate/chitosan nanoparticles: Preparation, characterization and soil sorption studies. J. Hazard. Mater. 2011, 190, 366-374. [CrossRef] [PubMed]

103. Grillo, R.; dos Santos, N.Z.P.; Maruyama, C.R.; Rosa, A.H.; de Lima, R.; Fraceto, L.F. Poly (E-caprolactone) nanocapsules as carrier systems for herbicides: Physico-chemical characterization and genotoxicity evaluation. J. Hazard. Mater. 2012, 231, 1-9. [CrossRef] [PubMed]

104. Grillo, R.; Rosa, A.; Fraceto, L.F. Poly ( $\varepsilon$-caprolactone) nanocapsules carrying the herbicide atrazine: Effect of chitosan-coating agent on physico-chemical stability and herbicide release profile. Int. J. Environ. Sci. Technol. 2014, 11, 1691-1700. [CrossRef]

105. Grillo, R.; Pereira, A.E.; Nishisaka, C.S.; de Lima, R.; Oehlke, K.; Greiner, R.; Fraceto, L.F. Chitosan/ tripolyphosphate nanoparticles loaded with paraquat herbicide: An environmentally safer alternative for weed control. J. Hazard. Mater. 2014, 278, 163-171. [CrossRef] [PubMed]

106. Grillo, R.; Clemente, Z.; de Oliveira, J.L.; Campos, E.V.R.; Chalupe, V.C.; Jonsson, C.M.; de Lima, R.; Sanches, G.; Nishisaka, C.S.; Rosa, A.H. Chitosan nanoparticles loaded the herbicide paraquat: The influence of the aquatic humic substances on the colloidal stability and toxicity. J. Hazard. Mater. 2015, 286, 562-572. [CrossRef] [PubMed]

107. De Oliveira, J.L.; Campos, E.n.V.R.; Gonçalves da Silva, C.M.; Pasquoto, T.; Lima, R.; Fraceto, L.F. Solid lipid nanoparticles co-loaded with simazine and atrazine: Preparation, characterization, and evaluation of herbicidal activity. J. Agric. Food Chem. 2015, 63, 422-432. [CrossRef] [PubMed]

108. Maruyama, C.R.; Guilger, M.; Pascoli, M.; Bileshy-José, N.; Abhilash, P.; Fraceto, L.F.; de Lima, R. Nanoparticles based on chitosan as carriers for the combined herbicides imazapic and imazapyr. Sci. Rep. 2016, 6. [CrossRef] [PubMed]

109. Yu, Z.; Sun, X.; Song, H.; Wang, W.; Ye, Z.; Shi, L.; Ding, K. Glutathione-Responsive Carboxymethyl Chitosan Nanoparticles for Controlled Release of Herbicides. Mater. Sci. Appl. 2015, 6, 591-604. [CrossRef]

110. De Oliveira, C.R.; Fraceto, L.F.; Rizzi, G.M.; Salla, R.F.; Abdalla, F.C.; Costa, M.J.; Silva-Zacarin, E.C.M. Hepatic effects of the clomazone herbicide in both its free form and associated with chitosan-alginate nanoparticles in bullfrog tadpoles. Chemosphere 2016, 149, 304-313. [CrossRef] [PubMed]

111. Tong, Y.; Wu, Y.; Zhao, C.; Xu, Y.; Lu, J.; Xiang, S.; Zong, F.; Wu, X. Polymeric Nanoparticles as a Metolachlor Carrier: Water-Based Formulation for Hydrophobic Pesticides and Absorption by Plants. J. Agric. Food Chem. 2017, 65, 7371-7378. [CrossRef] [PubMed]

112. Jacques, M.T.; Oliveira, J.L.; Campos, E.V.; Fraceto, L.F.; Ávila, D.S. Safety assessment of nanopesticides using the roundworm Caenorhabditis elegans. Ecotoxicol. Environ. Saf. 2017, 139, 245-253. [CrossRef] [PubMed]

113. Schnoor, B.; Elhendawy, A.; Joseph, S.; Putman, M.; Chacón-Cerdas, R.; Flores-Mora, D.; Bravo-Moraga, F.; Gonzalez-Nilo, F.; Salvador-Morales, C. Engineering Atrazine Loaded Poly (lactic-co-glycolic Acid) Nanoparticles to Ameliorate Environmental Challenges. J. Agric. Food Chem. 2018, 66, 7889-7898. [CrossRef] [PubMed]

114. Baulcombe, D. RNA silencing in plants. Nature 2004, 431, 356-363. [CrossRef] [PubMed]

115. Bartel, D. MicroRNAs: Genomics, biogensis, mechanism and function. Cell 2004, 116, 281-297. [CrossRef]

116. Burand, J.P.; Hunter, W.B. RNAi: Future in insect management. J. Invertebr. Pathol. 2013, 112, S68-S74. [CrossRef] [PubMed]

117. Maillard, P.; Ciaudo, C.; Marchais, A.; Li, Y.; Jay, F.; Ding, S.; Voinnet, O. Antiviral RNA interference in mammalian cells. Science 2013, 342, 235-238. [CrossRef] [PubMed]

118. Borges, F.; Martienssen, R.A. The expanding world of small RNAs in plants. Nat. Rev. Mol. Cell Boil. 2015, 16, 727-741. [CrossRef] [PubMed] 
119. Robinson, K.E.; Worrall, E.A.; Mitter, N. Double stranded RNA expression and its topical application for non-transgenic resistance to plant viruses. J. Plant Biochem. Biotechnol. 2014, 23, 231-237. [CrossRef]

120. Mitter, N.; Worrall, E.A.; Robinson, K.E.; Xu, Z.P.; Carroll, B.J. Induction of virus resistance by exogenous application of double-stranded RNA. Curr. Opin. Virol. 2017, 26, 49-55. [CrossRef] [PubMed]

121. Li-Byarlay, H.; Li, Y.; Stroud, H.; Feng, S.; Newman, T.C.; Kaneda, M.; Hou, K.K.; Worley, K.C.; Elsik, C.G.; Wickline, S.A. RNA interference knockdown of DNA methyl-transferase 3 affects gene alternative splicing in the honey bee. Proc. Natl. Acad. Sci. USA 2013, 110, 12750-12755. [CrossRef] [PubMed]

122. Thairu, M.; Skidmore, I.; Bansal, R.; Nováková, E.; Hansen, T.; Li-Byarlay, H.; Wickline, S.; Hansen, A. Efficacy of RNA interference knockdown using aerosolized short interfering RNAs bound to nanoparticles in three diverse aphid species. Insect Mol. Boil. 2017, 26, 356-368. [CrossRef] [PubMed]

123. Das, S.; Debnath, N.; Cui, Y.; Unrine, J.; Palli, S.R. Chitosan, carbon quantum dot, and silica nanoparticle mediated dsRNA delivery for gene silencing in Aedes aegypti: A comparative analysis. ACS Appl. Mater. Interfaces 2015, 7, 19530-19535. [CrossRef] [PubMed]

124. Zhang, X.; Zhang, J.; Zhu, K. Chitosan/double-stranded RNA nanoparticle-mediated RNA interference to silence chitin synthase genes through larval feeding in the African malaria mosquito (Anopheles gambiae). Insect Mol. Boil. 2010, 19, 683-693. [CrossRef] [PubMed]

125. Zhang, X.; Mysore, K.; Flannery, E.; Michel, K.; Severson, D.W.; Zhu, K.Y.; Duman-Scheel, M. Chitosan/ interfering RNA nanoparticle mediated gene silencing in disease vector mosquito larvae. J. Vis. Exp. JoVE 2015. [CrossRef] [PubMed]

126. Koch, A.; Biedenkopf, D.; Furch, A.; Weber, L.; Rossbach, O.; Abdellatef, E.; Linicus, L.; Johannsmeier, J.; Jelonek, L.; Goesmann, A. An RNAi-based control of Fusarium graminearum infections through spraying of long dsRNAs involves a plant passage and is controlled by the fungal silencing machinery. PLoS Pathog. 2016, 12, e1005901. [CrossRef] [PubMed]

127. Wang, M.; Weiberg, A.; Lin, F.-M.; Thomma, B.P.; Huang, H.-D.; Jin, H. Bidirectional cross-kingdom RNAi and fungal uptake of external RNAs confer plant protection. Nat. Plants 2016, 2, 16151. [CrossRef] [PubMed]

128. Ghosh, S.K.B.; Hunter, W.B.; Park, A.L.; Gundersen-Rindal, D.E. Double strand RNA delivery system for plant-sap-feeding insects. PLoS ONE 2017, 12, e0171861. [CrossRef] [PubMed]

129. San Miguel, K.; Scott, J.G. The next generation of insecticides: DsRNA is stable as a foliar-applied insecticide. Pest Manag. Sci. 2016, 72, 801-809. [CrossRef] [PubMed]

130. Kookana, R.S.; Boxall, A.B.A.; Reeves, P.T.; Ashauer, R.; Beulke, S.; Chaudhry, Q.; Cornelis, G.; Fernandes, T.F.; Gan, J.; Kah, M.; et al. Nanopesticides: Guiding Principles for Regulatory Evaluation of Environmental Risks. J. Agric. Food Chem. 2014, 62, 4227-4240. [CrossRef] [PubMed]

131. Mishra, S.; Keswani, C.; Abhilash, P.; Fraceto, L.F.; Singh, H.B. Integrated Approach of Agri-nanotechnology: Challenges and Future Trends. Front. Plant Sci. 2017, 8, 471. [CrossRef] [PubMed]

132. Arts, J.H.; Hadi, M.; Keene, A.M.; Kreiling, R.; Lyon, D.; Maier, M.; Michel, K.; Petry, T.; Sauer, U.G.; Warheit, D. A critical appraisal of existing concepts for the grouping of nanomaterials. Regul. Toxicol. Pharmacol. 2014, 70, 492-506. [CrossRef] [PubMed]

133. Parisi, C.; Vigani, M.; Rodríguez-Cerezo, E. Agricultural Nanotechnologies: What are the current possibilities? Nano Today 2015, 10, 124-127. [CrossRef]

(C) 2018 by the authors. Licensee MDPI, Basel, Switzerland. This article is an open access article distributed under the terms and conditions of the Creative Commons Attribution (CC BY) license (http://creativecommons.org/licenses/by/4.0/). 